\title{
北イエメンにおける伝統的地域区分と部族 The Traditional Regional Divisions and Tribes in North Yemen
}

\begin{abstract}
The subject of my research is the relationship between tribal structures and regional divisions in North Yemen. The research is organized into three parts: (a) the current situation of tribes and rural administrative divisions; (b) the history of traditional regional divisions in medieval times; and (c) the evolution of traditional regional divisions to the rural administrative divisions of North Yemen in the modern era. This article draws on (b).
\end{abstract}

The terms mikhlāf and ${ }^{c}$ uzlah are the indigenous titles of the Yemeni regional divisions. However it is not clear what they comprise since there has been insufficient research on Yemeni regional divisions. References to the mikhlāf and 'uzlah in three classic texts, al-Hamdānī's Șifah Jazīrah al${ }^{c}$ Arab, Yāqūt's Mucjam al-Buldān and al-Hajarī's Majmūc Buldān al-

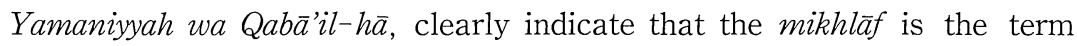
used to describe the regional division in the southern highlands of North Yemen during the medieval period, while the ${ }^{c}$ uzlahs are sub-divisions of the mikhlāf.

Next, I study the tribal genealogies (al-Hāmdanī's Kitāb al-Iklìl and the above Yāqūt's text) to trace the ancestry of the component tribes of the mikhläfs. This indicates that the tribes of Himyar al-Humaysa ${ }^{c}$ were the most influential, especially those tribes descending from Jusham in the genealogies. Thus, it can be said that the mikhlāf and ${ }^{c} u z l a h$ are historically the indigenous structure of regional divisions in the southern highlands of North Yemen, in which the component tribes of those are the Jusham tribes.

* (財)日本国際問題研究所主任研究員

Senior Research Fellow, The Japan Institute of International Affairs 


\section{I.はじめに}

筆者はこれまで，北イエメン（1990年南北イエメン統一・イエメン共和国成 立以前の，イエメン・アラブ共和国の範囲）の部族と地域区分の関係に関し， (A)現在の地方行政区分と部族の関係 [松本 1996],(B)中世におけるイエメン固有 の伝統的地域区分と部族との関係，(C)近現代において伝統的地域区分が地方行 政区分に変容していく過程 [松本 1998］の3部構成で研究を試みた。本稿は，上 記(B)にあたるものである。紙数の制約から，上記既発表論文に述べられた問題 関心及び同論文の内容についての説明は割愛するが，本稿の論述のために必要 な限りの，北イエメンの部族と地域区分の概要は以下の通りである。

イエメンの諸部族は南アラブに属し，かつカハターンの子孫であるサバ Saba'を共通の祖先とする。サバには 2 人の息子, ヒムヤル Himyar とクフラ ーン Kuhlān がおり，部族の伝説的系譜は，まずこの 2 系統に分かれる。ヒム ヤル系はその 2 人の息子から，さらにヒムヤル・アル = フマイサア Himyar alHumaysa $^{\mathrm{c}}$ とヒムヤル・アル = クダーア Himyar al-Qudā̄ah に分かれる。ク フラーン系もその子孫から, ハムダーン Hamdān, クフラーン・マズヒジュ Kuhlān Madhhij, その他に分かれ，ハムダーンはさらにハーシド Hāashid とバ キール Bakīl に分かれる。これらの名称はすべて系譜上の人名であり，それは 部族の系統を表している。部族 qabīlah とは，ここからさらに系譜が下って， 系統を表わす各人のいずれかの子孫を共通の祖先とする集団を意味している。 それゆえ，部族の名称もその系統と同じく，各部族の系譜に基づいた人名とな っている例が多い。

また，北イエメンにおける地方行政区分は，州 muhāfazah一郡 qad̄ā'ーナー ヒヤ nāhiyahーウズラ ${ }^{\mathrm{c}} \mathrm{uzlah}$ (pl. ${ }^{\mathrm{c}} \mathrm{azal}$ ) - 村 qaryah という 5 レベルの階層的 地域区分から成っている（それぞれ上位の地域区分は，より小規模な下位の地 域区分の集合体)。そこでは，一般にナーヒヤが部族に対応し，ウズラがセクシ ヨン（部族を構成する下位集団）に，村が拡大家族（セクションを構成する下 位集団）に対応している。つまり，部族一七クションー拡大家族という部族構 造に対して，ナーヒヤーウズラー村という地域区分構造が，それぞれに対応す るかたちで設けられている。ところが, ナーヒヤという呼称は全国一律なのに 対し，ウズラ・レベルの地域区分は，公式な呼称であるウズラの他にも，実際 にはナーヒヤによって「 4 分の $\left.1 \mathrm{rub}^{\mathrm{c}}\right\rfloor 「 5$ 分の $1 \mathrm{khums}$ といった単分数やミ 
フラーフ mikhlāf (pl.makhālīf) という呼称も使われている。単分数の場合 は，イエメンでは古代からセクションに対する呼称に単分数が用いられており [Beeston and others 1982: 132，150]，それが地域区分の呼称に転用されたも のと考えられる。

しかし，ウズラやミフラーフという呼称はイエメン固有の言葉であり，呼称 からだけではその意味するところはわからない。では，このウズラとミフラー フとは，一体いかなるものなのか。これが本稿の主題であり，ウズラとミフラ 一フの歴史を追いながら，それら伝統的地域区分と部族との関係を明らかにす ることが，以下の論述の目的となる。

しかし，この作業にはいくつかの問題点が存在する。第一に，後に用いる中 世の各地理書には，地域区分の地名と位置しか記されておらず，その厳密な境 界や範囲はわからない。それゆえ，その範囲は現在の地域区分から推定する以 外に方法がなく，その地理的な特定は極めて大まかなものとなる。第二に，部 族と地域区分の関係を歴史的に調べる場合，それは部族名と地域区分の地名と の照合が基本となる。しかし各地理書に，ある地域区分にはある部族が居住し ていると記されていても，その地域区分に当該部族以外の住民がいないという ことはありえない。それゆえ以下の論述で，地域区分とその住民である部族と いった表現をする場合でも，それはその地域区分が，大勢として特定の部族に 占められているという意味であり，その地域区分と部族の領域が一致している という意味ではない。

第三に，ウズラやミフラーフという地域区分の呼称については，住民自らが そう呼んでいるのか，外部の他者（たとえば，記録者）からそう呼ばれている だけなのかを，判別しなければならない。しかし，その確定的な判別基準は資 料そのものからは得られず，それは各資料の比較検討から推定する以外にない。 また，現在のミフラーフは，地域区分の呼称としてのみ用いられるが，過去に は幅広い意味を有していた。それは一般的な「地方」「地域」「「方面」という 意味で用いられるほか, ミフラーフの複数形に定冠詞を付けた al-makhālif は，それ自体で「イエメンの諸地方」を意味する場合があるし，さらには「諸 ミフラーフの人々 ahl al-makhālif」という表現はイエメン人を，「諸ミフラー フの集まり jamī ${ }^{\mathrm{c}}$ al-makhālif」 という表現はイエメンそのものを意味した [Yahyā 1968, I: 153，180，184，209，243，249，367]。このため, 資料中の 
様々なミフラーフのなかから，特定の地域区分の呼称としてのミフラーフを特 定し，それに限って議論を行わなければならない。

以上の問題点に留意しつつ，歴史的にはイエメンそのものの代名詞となる場 合もあったミフラーフから，その歴史と部族との関係を論じることとする。

\section{II. 伝統的地域区分と部族との関係}

1. ミフラーフとウズラに関するこれまでの定義

ミフラーフそのものに関する先行研究はない。しかし，それについては断片 的ながら，以下のような説明がなされている。イエメンの前イスラーム期の言 葉であるサバ語では，ミフラーフに相当する HLFは「町の門」，「地域」，「町の 近辺」を意味していた [Beeston and others 1982: 60]。マドアジュは，「イスラ 一ムの初期，イエメンは有力な部族の割拠状態にあり，各部族はそれぞれの地 域 province（mikhlāf）を支配していた。」Madcaj 1988: 5] と述べているが， その典拠は示されていない。12世紀の詩人ナシュワーン (d.573/1177 or 8) は,

「ミフラーフはイエメン人の言葉で地域 al-kurah を意味し，またその地域の 集まりをも意味する。」Nashwān 1981: 34] と述べ，13世紀の旅行家イブン・ アルンムジャーウィル (601-90/1204 or 5-1291) は，「各ミフラーフは高地の砦 を有しており，砦の周囲に村や耕地がある。ミフラーフとはイエメンの高地に のみ存在する, 大規模な地域を表わす言葉である。」[Ibn al-Mujāwir 1986: 16970）と述べている。同じ13世紀のヤークート（後述）はミフラーフを，「地域の 所在地であり，部族の名称でもある。」[Yāqūt 1955, V: 67] と述べ，今世紀半 ばのハジャリー（後述）は，「ミフラーフは，多くの［より小規模な］地域から

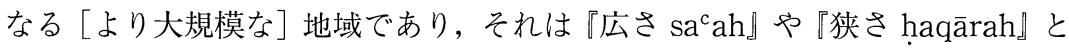
いった言葉とは異なるものである [一般的な『地域』を意味しない］。そして常 に，地名とともに用いられる。」Hajarī 1984，II: 697] と述べている。

またアクワも上記ヤークートと同様に，ミフラーフを「地域であり，かつ部 族に関わる表現」 $\left[\mathrm{Akwa}^{\mathrm{c}}\right.$ 1987: 81-2] としているし，アブー・ガーニムは，「ミ フラーフとウズラは, 古代ヒムヤル時代からヤリーム Yarim とイッブ Ibb の 地方にあった地域区分」 [Abū Ghānim 1985: 65] と記しているが，残念ながら これらにもその典拠は示されていない。一方，ボスワースはミフラーフを，「特 にイエメンで用いられる，中世イスラームの行政地理の用語」[Bosworth 1993: 
35]としている。それ以上の説明は述べられていないが，おそらくこれは，17 世紀のイエメン・ザイド派の年代記『イエメンの記録における平安の極致』の中 の「ミフラーフの支配者 șāhib mikhlāf」[Yahyā 1968, I: 288-9, 292] という 記述や，ウィルソンの以下の論述に基づく推察であると思われる。

イエメンの歴史的資料の大半が，ミフラーフという言葉を非常にあいま いに用いている。少数の資料が厳密に用いているものの，一般的には不特 定の地域を指している。Sìrat al-Hādī[イエメン・ザイド派イマームの伝記］ はミフラーフを, 飼料税徴収に関係する村々と記しており, 行政的な意味 を示唆している。ヤアクービー（後述）は，ミフラーフの定義を試みて， それは地域 kuwar や町 mudun と同様なものと大まかに述べている。ハム ダーニー (後述) が記したミフラーフの内, いくつかにはその中心地が述 べられ，ごく少数にその支配者が記されているが，[中略］そのほかは中心 地も支配者も存在しないようである。[Wilson 1989: 43]

確かにザイド派の諸資料のごく一部には，ミフラーフという地域区分が，地方 の政治や行政に関わるかのように記されているが，その細かな状況は述べられ ていない。そもそも中世において，イエメンに地方行政に類するものが存在し たかどうかについても，現在のところ明らかではない。それゆえ，ミフラーフ を中世の行政区分と考えることには，筆者は疑問を持っている。

一方，ウズラについては，より少数の断片的な説明しか確認できない。それ らによればウズラとは，国家の権威が及ばない伝統的な地方自治の状況にあり， 一般に特定のワーディ一流域や山腹, 農耕地内の村々によって構成される $[\mathrm{e}$. g. , 'Azāzī and Kurūzah 1975: 255-6; Steffen 1979: I/47-8]。しかし,これらは すべて, 現代の研究者によるウズラの現状に関する説明であり, 筆者の知る限 り中世や近代の諸資料には，ウズラの説明は出てこない。

要するに, 以上のような断片的な記述をいくら集めても，ミフラーフとウズ ラが一体何であるのかは，一向に見えてこない。両者が部族に関係した地域区 分であることは明らかだが，それ以上のことは，過去の説明とは異なる方向か ら調べていく必要がある。

\section{2. 資料批判}

ミフラーフとは何かを考えるのであれば，まずイエメンにおけるすべてのミ フラーフを確認しなければならない。諸資料のなかには個々のミフラーフに言 
及しているものも多いが，筆者の知る限り，すべてのミフラーフを記述してい る資料は, 以下の 6 点の地理書のみである。

(1) ヤアクービー (d.284/897), 『諸国の書』[Yac qūbī 1892: 317-9]

(2) イブン・フルダーズベ (205 or 211-300/820 or 825-911), 『諸街道と諸王国 の書』[Ibn Khurdādhbih 1889: 136-43]

(3) ハムダーニー（280-350 or 360/893-961 or 971),『アラビア半島地誌』 [Hamdānī 1990] (以下, SA)

（4）ムカッダシー（d.381/990）、地域区分に関わる詳解』[Muqaddasī 1906: 88-92]

(5) ヤークート (575-626/1179-1229), 『地名辞典』[Yāqūt 1955] (以下，MB)

（6）ハジャリー（1307-80/1890-1960)，『イエメン地名・部族名辞典』[Hajarī 1984]（以下, YQ)

しかし，これら 6 点の内，少なくともミフラーフの考察のための資料として は，(1)，(2)，(4)は不適当である。というのも，上記 6 地理書以外の諸資料にも， イエメンの各地域区分は散見するが，それらには地域区分や地方によってミフ ラーフのみならずナーヒヤ, アウマール a $a^{\mathrm{c}} \mathrm{mā}$, ビラード bilād といった数種 類の呼称が確認できる。ところが(1)，(2)，(4)は，それぞれイエメンの項目に75， 84，67の地名を挙げているが，そのすべてに呼称としてミフラーフが用いられ ており，その地理的範囲も北イエメンのほぼ全域に及んでいる。これでは，ミ フラーフが特定の地域区分を表しているのか, 単にイエメンの諸地方を列記し ただけなのか, 判定できない。おそらくは, ミフラーフがイエメン固有の地域 区分呼称であることから，著者が地域区分の地名すべてにミフラーフを付した 結果と考えられるが, その中から本当のミフラーフを確認することは, 極めて 困難である。

一方, $\mathrm{SA}, \mathrm{MB}, \mathrm{YQ} の 3$ 点は, いずれもミフラーフと他の呼称を地域区分に よって使い分けており，ミフラーフの地理的範囲も北イエメンのある部分を占 めているに過ぎない。これならば, 上記 6 地理書以外の諸資料の記述とも一致 するし，ミフラーフが特定の地域区分を表していることも明らかである。加え て(1)，(2)，(4)がミフラーフの地名を列記するのみであるのに対し， SA， MB， YQ はミフラーフを含む各地域区分に関して, そのすべてではないが, 当該地域 区分の住民である部族に言及している。 
$\mathrm{SA}$ の著者であるハムダーニーと, $\mathrm{YQ}$ の著者であるハジャリーはイエメン人 であり, 前者はイエメンの地理や歴史に関する学者, 後者はイエメン・ム夕ワ ッキル王国（1918-62）時代のワクフ行政の専門家であった。両者とも，北イエ メン各地の状況に精通しており，その記述の信憑性は高い。MBの著者であるヤ ークートは, イエメン人ではなくイエメンを訪れたこともないが, 彼は SA を含 むイエメンに関する複数の地理書に加え，多くのイエメン人から直接情報を得 ており [Yāqūt 1988: 10-2]，そのミフラーフに関する記述は SA，YQ と同様に 他の地域区分と区別し，かつ部族への言及を含んでいる。

但し，ヤークートは八ムダーニーの著作を用いているし，八ジャリーは八ム ダーニーとヤークートの著作を用いている。このため, MB 及び $\mathrm{YQ}$ の記述に 関しては，それがその当時の状況を表しているものか，過去の資料からの引用 なのかを区別し，前者の記述を対象として議論を行わなければならない。八ジ ヤリーは部族の系譜に関しては $\mathrm{MB}$ を引用しているが，ミフラーフの地名は $\mathrm{SA}, \mathrm{MB}$ のもとは異なっている。さらに $\mathrm{YQ}$ におけるウズラの記述は，それ までの資料には見られないもので，ハジャリー自身が調べ記したものであるこ とは疑いない。それゆえ，ミフラーフ，ウズラを含む北イエメンの地域区分や その居住部族に関しては，YQは SA に劣ら資料的価值を有している。

$\mathrm{MB}$ に関しては, 後述するようにそのミフラーフの中には, 特定の地域区分と 見なすには疑問があるものもある。それゆえ，MBの信憑性は上記(1), (2)，(4)の 資料と SA，YQ との中間に位置するといえよう。しかし，そのミフラーフと部 族の系譜についての記述は，ハムダーニーのものと決して同一ではない。ミフ ラーフについては同じものもあれば，異なるものもある。系譜も基本的な枠組 みは重なっているが，MBのみに記されたミフラーフに対応するかたちで異な る部分もある。それらの違いが, 当時の状況をどの程度表わすものかは判定し 難いが，SA，YQに次ぐ資料として，ミフラーフの考察に援用するだけの価值 はあると考える。そこで本稿では, $\mathrm{SA}, \mathrm{MB}, \mathrm{YQ} の 3$ 点の資料を用いることと したい。

\section{3. 資料の中のミフラーフとウズラ}

最初に，SA 及び MB に記されたミフラーフを見てみると，それは末尾の表 1，2のようになっている。加えて，その地理的な分布を示す地図 1,2 を付 したが, 既述のようにその厳密な特定は不可能である。それゆえ地図について 
は，後の YQに関わる地図も含めて大まかなものであり，地図上の斜線はその 範囲内にミフラーフが存在することを示しているにすぎず，決して明確な境界 を表わすものではないことを明記しておく。

SA は, 計28のミフラーフを記している。そのうち現在のアシール地方に存在

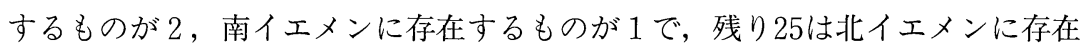
している。そして北イエメンのミフラーフは，地図 1 にあるように首都サナア （地図上○で表示）より南方の, 南部高原地帯に集中している。また部族との 関係では，部族の記載がない 3 ミフラーフを除いた 25 のう，ヒムヤル系の部 族のみによって占められているミフラーフが11，クフラーン系の部族のみによ って占められているミフラーフが2（クフラーン・マズヒジュ 1 ，その他 1 ） あり，残り 12 ミフラーフは両系統の諸部族による混住となっている。但し，そ の記述の内容から混住のミフラーフの中で, ヒムヤル系の部族が優勢と見られ るものが 5 (表 $1: \operatorname{nos} .2,3 ， 4 ， 14,19$ ), クフラーン・マズヒジュの部族が優勢 と見られるものが 3 (表 $1: \operatorname{nos} .8 ， 9 ， 15$ ) ある。

MBでは, 計119のミフラーフが記されている。そのうち12がアシール地方に， 9 が南イエメンに存在し，位置を特定できなかったものが23ある。それゆえ， 北イエメンのミフラーフは75となる。北イエメンのミフラーフの分布は, 地図 2 にあるようにSAの範囲を大きく上回り, 南部高原地帯から北方, 西方, 東方 に広がっている。しかし, 南部高原地帯以外に存在するミフラーフは大規模な ものが多く（特に表 $2: \operatorname{nos} .64,90,112$ ), それらが特定の地域区分であるかど うか，またそうであっても，位置や地図で示したほど大規模であるかどうかに ついては, 確証はない。反面, 南部高原地帯内のミフラーフは, その数が増加 フラーフの大半が複数の部族の混住であったのに対し, $\mathrm{MB}$ のミフラーフには,

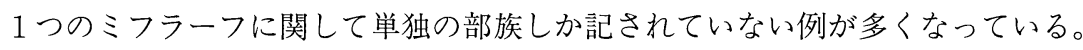
その部族との関係では, 部族が記載されていないもの及び記載された部族の 系統が不明なものが69あり，部族との関係を考察できるのは，50ミフラーフと なっている。そのうち，ヒムヤル系の部族が占めているミフラーフは29（ヒム ヤル・アル = フマイサア 23, ヒムヤル・アル = クダーア 5, どちらか不明のもの 1), クフラーン系の部族が占めているミフラーフは20（クフラーン・マズヒジ ュ 7 , ハムダーン 6 , その他 7 ), 両系統の諸部族が混住するミフラーフは 1 (表 
2: no.86) となっている。

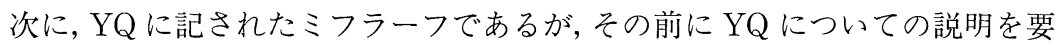
する。この資料はイエメン・ムタワッキル王国時代の1940年代に記されたもの と考えられる。当然, 近代以降のものであり, かつ北イエメンの各地域区分は, 第二次オスマン占領期（1872-1918）に導入され，同王国期に拡大された地方行 政区分によって変容していく過程にあった。その地方行政区分の構成は，冒頭 で述べた州一郡一ナーヒヤーウズラー村というものであるが，しかし YQに記 された北イエメン全土の地方行政区分は，これとは大きく異なる様相を呈して いる。そして，そこには当時のミフラーフとウズラがすべて記されており，そ の状況も現在とは全く異なっている。筆者はこれについて, 地域区分が変容し ていく過渡期にあって，5段階の地方行政区分の下部の部分は，まだ伝統的地 域区分の多くがそのまま残存していた状況にあったと考えている。YQの著者 ハジャリーは，自らが記した地方行政区分はヒジュラ暦1360年 (1941/2 年) に 改編されたものと述べているが，同書の内容（表 3 ）を見ると，その改編はナ 一ヒヤより上部のみを対象としていたとしか思えない。

表 3 に示したように, 当時の地方行政区分には統一性が無く, それは各地方 によって様々な形態をとっている。そのなかで, ミフラーフはナーヒヤ・レべ ルの地域区分であるものが13, 現在でも見られるようなウズラ・レベルの地域 区分であるものが76となっている（YQにおける北イエメン以外のミフラーフ

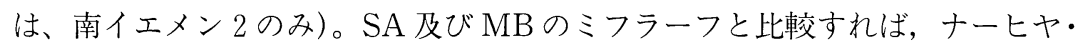
レベルのミフラーフ，ナーヒヤ・レベルのミフラーフによって構成される郡, ウズラ・レベルのミフラーフによって構成されるナーヒヤが, SA または MB の ミフラーフに相当する例が見られる。これらミフラーフの地理的分布を示した ものが地図 3 であるが，その分布はやはり南部高原地帯に集中しており，概ね 10世紀の SAのミフラーフの範囲と重なっている。範囲が重なっているのに, ミ フラーフの数が SA に比して多いのは, 上記のように SA のミフラーフが地方 行政区分導入の過程で細分化され，それ以前よりも下位の各地域区分の呼称と なっているからである。それゆえ, SA及び MBのミフラーフの地名は, YQの ナーヒヤの地名となっているものが多い。

表 4 は, YQ に記された各ミフラーフと部族との関係を示したものだが, ナー ヒヤ・レベルの 13 ミフラーフでは, クフラーン系の部族（クフラーン・マズヒ 
ジュでも八ムダーンでもない）が 7 を占め，記載がなく不明のものが 6 となっ ている。ウズラ・レベルの76ミフラーフでは, 34 がヒムヤル系（ヒムヤル・ア ル=フマイサア 33, ヒムヤル・アル = クダーア 1 ) , 26がクフラーン系 (クフラー

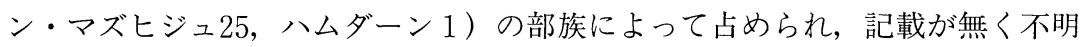
のものが16となっている。

一方，YQ はウズラに関する最も重要な資料でもある。ミフラーフと同様，イ エメンにおけるすべてのウズラも確認しなければならないが，それが可能であ る最初の資料は，この YQである。筆者が調べた限り，中世にはごく少数の資 料が, 若干のウズラに言及しているに過ぎない。しかし, 少数でも記述がある のだから, ウズラが近代の地方行政区分導入以前から, イエメンに存在したこ とは疑いない。イエメン固有の地域区分の呼称であり，現在では北イエメン全 土の地方行政区分となっているウズラが，中世の資料にほとんど出てこないの は何故なのか。

表 3 に記されたウズラの総数は 531 に及び, その分布は地図 4 に示した通りで

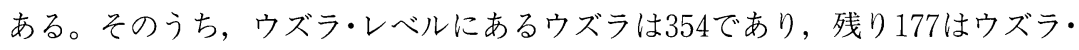
レベルにあるミフラーフと村の中間という，上記 5 段階の地方行政区分からす れば変則的な位置にある。すなわち，ナーヒヤーウズラー村という 3 段階の部 分が, この177ウズラが存在するナーヒヤでは, ナーヒヤーミフラーフーウズ ラー村という4 段階となっている。このような例は，ウズラ以外の呼称を持つ 地域区分には見られない。ウズラのみが，ウズラ・レベルのミフラーフを構成 する下位の地域区分となっている。

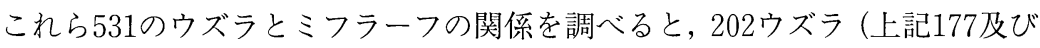
ナーヒヤ・レベルの 2 ミフラーフを構成する25ウズラ）が YQのミフラーフを

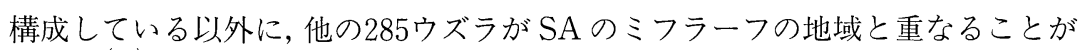
判明した。そその結果, SA及び $\mathrm{YQ}$ のミフラーフと無関係のウズラは44にすぎ ず，YQに記された531ウズラの $91 \%$ にあたる487ウズラが, SA または YQのミ フラーフと関係することが明らかとなった。

筆者は以上の事実から，ミフラーフとは南部高原地帯における固有の地域区 分であり，ウズラとはそのミフラーフを構成する下位のより小規模な地域区分 であったと考える。10世紀の SAに記されたミフラーフは, そのほとんどが南部 高原地帯に分布していた。13世紀の MBにおいて, その地理的範囲は拡大した 
が，1940年代の YQではミフラーフは再び南部高原地帯に集中している。そし て, YQに記されたウズラについても, その大半が南部高原地帯に分布するとと

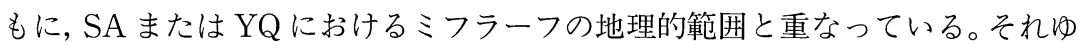
え, 中世の北イエメン南部高原地帯には, ミフラーフーウズラという地域区分 構造が存在していたということが，両者に関する筆者の第一の仮説となる。

中世の資料にウズラが言及されない理由は，それがミフラーフと村の中間と いう，中途半端な位置にある小規模な地域区分であったことに求められよう。 歴史書で何がしかの記述を行う際には，ミフラーフや村の地名に言及すれば十 分である。地理書においても，ウズラが極めて多数存在することから，その確 認や列記は省かれ，より上位のミフラーフへの言及に止めたものと考えられる。

4. 部族の系譜とミフラーフ

ミフラーフとウズラの地理的な特性については, Uとまず以上のような仮説 を示すことができたが，ではその部族との関係については，いかなる仮説が可 能となるか。上に記した $\mathrm{SA}, \mathrm{MB}, \mathrm{YQ} の$ 各資料におけるミフラーフと部族の 関係では，ヒムヤル系の諸部族が居住するミフラーフが，常にクフラーン系の ものより多かった。SAには部族の系譜に関する記述はないが, 著者のハムダー ニーには『王冠の書』[Hamdānī 1986]（以下，KI）という別の著作があり，そ の第二巻ではヒムヤル系諸部族の系譜が記されている。SAでは既述のように，

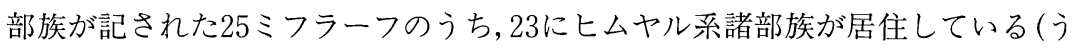
ち12はクフラーン系諸部族との混住)。これら諸部族を KI の系譜と照らし合わ せてみると，そのうちの 17 ミフラーフの居住部族を系譜上に確認できる。居住 部族がヒムヤル・アル＝フマイサアに属するミフラーフは 16, ヒムヤル・アル =クダーアに属するミフラーフは 1 （表 1: no.21）であった。そして MB 及び $\mathrm{YQ}$ でも, ミフラーフの居住部族は, ヒムヤル・アル＝フマイサアに属するもの が最も多かった。

そこで, ミフラーフとヒムヤル・アル = フマイサアの系譜との関係を, 以下に 見ることとする。SAのミフラーフに関しては，上記 KIに記された系譜のヒム

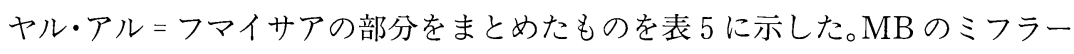
フに関しては，同書のミフラーフの項目でヤークートが記した当該部族の系譜 を集め, それをまとめたものを表 6 に示した。YQについては, 著者のハジャリ 一が部族の系譜の部分を MB からの引用に頼っているため, この考察からは除 
外する。

系譜上の人名のうち, 斜体で表した人物は, ミフラーフの居住部族の名祖と なっているものである。細かな説明は割愛するが，系譜上の人名とミフラーフ を照合した結果, 以下のような指摘が可能であると考える。SAにおいて居住部 族が記されていた 25 ミフラーフのうち, KI の系譜上の人名には 16 ミフラーフの 居住部族名を確認できる（各ミフラーフに複数の居住部族が記されているため， 居住部族の名祖となっている系譜上の人物は 34 人)。16ミフラーフのうち，ミフ ラーフの地名と $\mathrm{KI}$ の系譜上の人名, 居住部族名が一致する例が 8 , ミフラーフ の地名と系譜上の人名が一致するが，居住部族名はそれとは異なる例が 1 , 系 譜上の人名と居住部族名が一致するが，ミフラーフの地名はそれとは異なる例 が 7 ある。一方, MBにおいて部族の系統が記されていた 50 ミフラーフのうち, $\mathrm{MB}$ の系譜上の人名には45ミフラーフの居住部族名を確認できる(ヒムヤル・ア ル = フマイサア 23, ヒムヤル・アル =クダーア 5, クフラーン・マズヒジュ 6, 八ムダーン 5 , その他のクフラーン 6 , 混住 1$)$ 。複数のミフラーフに居住する 部族があるため，ミフラーフと関係する系譜上の人物は 40 人であり，そのうち 21人がヒムヤル・アル = フマイサアに属し，その他の系統は計19人となってい る。45ミフラーフのうち，ミフラーフの地名と系譜上の人名, 居住部族名が一 致する例が 38 あ, ミフラーフの地名と居住部族名が一致するが, 系譜上にそ の名称を確認できない例が 3 , 系譜上の人名と居住部族名が一致するが，ミフ ラーフの地名はそれとは異なる例が 3 , 名称が全く一致しない例が 1 となって いる $(9)$ 。系譜上の人名と部族名が同じであるのは, 当該部族民がその人物を共 通の祖先と考え, 部族の名祖としていることから当然のことであるが，その名 称が地域区分の地名とも一致する例が多いことは，イエメン部族社会のひとつ の特色といえるだろう。

次いで, 最も多くのミフラーフと関係しているヒムヤル・アル＝フマイサアの 系譜を見てみると, ジュシャム Jusham という人物の子孫が, 大半のミフラー フの居住部族の名祖となっていることが分かる。KIの系譜では, その名祖34人 のうち, ジュシャムの兄弟が 3 人で, 残り 31 人がその子孫である。MBの系譜で

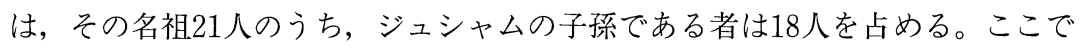
は仮に，ジュシャムの兄弟及び子孫を名祖とするミフラーフの居住部族を，以 下ジュシャム諸部族と呼ぶことにするが，このジュシャム諸部族に関しては， 
興味深いことがある。それは $\mathrm{YQ}$ に記された 531 ヴララのうち, SAのミフラー フに関係する285ウズラすべてと, YQのミフラーフに関係する202のうち, 居住 部族が記されていない 92 を除く110ウズラの計395ウズラが，ジュシャム諸部族 の居住するミフラーフに存在していることである (表 1,4 , 注 8 参照)。すなわ ち, ジュシャム諸部族以外の部族が居住するミフラーフには, ウズラを確認で きない。このことから筆者は, 上述した南部高原地帯におけるミフラーフーウ ズラ構造は，このジュシャム諸部族が用いていた地域区分とその呼称であると 考える。これが，ミフラーフとウズラに関する筆者の第二の仮説となる。

\section{III. 結 語}

上述した第一及び第二の仮説を合わせれば，筆者によるミフラーフとウズラ に関する説明は，以下のようになる。ミフラーフ及びウズラとは，中世の北イ エメン南部高原地帯における固有の地域区分であり，それは前者が後者によっ て構成される階層的な構造を有していた。そして, それはヒムヤル・アル = フマ イサアに属するジュシャム諸部族という，特定の部族の集団が居住する地域区 分であったと考えられる。第二次オスマン占領期の地方行政区分導入に際して は，南部高原地帯のミフラーフーウズラ構造の上にナーヒヤが乗るかたちとな り, その後ミフラーフとナーヒヤが融合する一方, ナーヒヤーウズラ構造が北 イエメン全土に拡大された。 $\mathrm{SA}, \mathrm{MB}$ に記されたミフラーフが，YQにおいて 郡やナーヒヤとなっているのは，この過程で生じた変容の結果である。そして ミフラーフは, 中世においてミフラーフであったナーヒヤの, ウズラ・レベル の地域区分の呼称として残っていったのである。

しかし，筆者によるこのような説明には，多くの例外が存在する。それは， クフラーン・マズヒジュ等の諸部族が居住するミフラーフであり, SA 及び $\mathrm{YQ}$ のミフラーフと関係の無い44のウズラである。また，イエメン史に関しては本 稿で述べたミフラーフよりもよく知られている,アル = ミフラーフ・アッ = スラ イマーニー al-Mikhlāf al-Sulaymānī 及びミフラーフ・ジャアファル Mikhlāf $\mathrm{Ja}^{\mathrm{c}}$ far の問題もある。これら 2 ミフラーフは, 中世の歴史書には数多く記述さ れているのに，地理書には一切出てこない。しかし，これらの例外や問題に関 する論述は，別の機会に譲ることとしたい。 
注

（1）本稿で用いる「地域区分」，「地方行政区分」については，人文地理ではそれぞれ 「地区」，「行政区域」という用語を用いている。筆者による「地域区分」，「地方行政 区分」という用語の使用に関しては，[松本1996: 104，n.1] を参照。

（2）北イエメンの場合，伝説的系譜に基づく部族一七クションー拡大家族という部族 構造が， 3 段階である例はむしろ稀で，部族やセクションが複数の段階を有している 例の方が多い。一般にセクションはbatn（腹）と呼ばれるが，大規模なセクションが 小規模なセクションとの対比によって, 部族 qabīlah と呼ばれることもある。しかし, ナーヒヤを占めるほどの大規模な集団がbatnと呼ばれることはない。また, batn より も下位レベルの集団は bayt, usrah, ciyāl（家，家族）などと呼ばれ，batnとは一線 を画される。それゆえ本稿では，北イエメンで一般に qabīlah と呼ばれる集団を部族， batn と呼ばれる集団をセクション, bayt 等と呼ばれる集団を拡大家族とした [松本 1996: 90, 96-101]。

（3）現在の地方行政区分のナーヒヤは，オスマン帝国の第二次イエメン占領に伴い設 置されたもの。このナーヒヤは同じ言葉ではあるが, イエメンに同占領以前から存在 した地域区分または地域，地方に関わる呼称であるので，両者は異なるものである。

（4）これら 3 地理書のミフラーフ数にはそれぞれ，アシール ${ }^{\mathrm{c} A s i r}$ 地方及び南イエメ ンのミフラーフ $11 ， 17 ， 6$ と，位置を確認できなかったミフラーフ17，14，16を含む。 それゆえ，各資料に記された北イエメンのミフラーフは，それぞれ47，53，45となる。 なお, 本稿で用いるアシール地方とは, 現在のサウジアラビア王国アシール州, ジー ザーン州, ナジュラーン州, バーハ州一帯を指す。

（5）本稿で用いる南部高原地带とは, 現在のムハーMukhā (モカ) 郡を除いたタイズ 州内陸部一帯, イッブ州全域, ダマール州全域, サナア州南部一帯を指す。

（6）ヤークートはMBの中で，既述のミフラーフの説明に加え，「ミフラーフの地域 nāhiyah mikhlāf, acmāl mikhlāf」,「それはミフラーフである hūwa mikhlāf」,「ミフ ラーフの名称 ism mikhlāf」といった表現を使っている [Yāqūt 1955, III: 40, 357; V: 68，136，433]。筆者はこれも，ヤークートがミフラーフを一般的な意味の地域ではな く, 特定の地域区分の呼称として用いている証左と考えている。

（7） MBには, Bahrānah という地名のウズラが1つ記されており，ヤークートはこれ を村としている [Yāqūt 1955, IV: 119]。ほかには，14〜15世紀の [Khazrajī 1983, I: 217; Janadī 1983, I: 226] に1つずつ, 19世紀半ばの [Sayyāghī 1984: 78] に 1 つのウ ズラが記されている。筆者が確認できたウズラの記述は，この 4 例にすぎない。

（8） YQの285ウズラが存在するナーヒヤと SAのミフラーフとの地理的な相関関係 は以下の通り（地名の前者は $\mathrm{YQ}$, 後者は SA)。ナーヒヤ Wușāb al-Sāfil はミフラー フ Na'mān。Raymah 郡はミフラーフ Jublān Raymah。ナーヒヤ Maghrib cAns は ミフラーフ Alhān wa Muqrīの一部。ナーヒヤ Jiblah, al-Makhādir, Hubaysh, Mudhayhirah, Dhī al-Sufāl, Sharcab はミフラーフ al-Sahūl。ナーヒヤ Yarīm, 
Khubān, al-Sabrah はミフラーフ Dhī Rucayn, al-c Awd wa Dhī Rucayn。ナーヒヤ Shibām wa Kawkabān はミフラーフ Aqyān の一部。ナーヒヤ Bura ${ }^{c}$ はミフラーフ Burac $^{c}$ 。ナーヒヤ Jabal Habashī (古名 Dhakhir), Șabir, Khadīr はミフラーフ alMacāfir の一部（表 1， 3 参照） [Hamdānī 1990: 194-6]。

（9）系譜上の人名と居住部族名が一致するミフラーフの総数が 38 と 3 で 41 となり，系 譜上の人物 40 人を上回るのは， 2 ミフラーフの居住部族が同一人物を名祖としている 例が 2,1 ミフラーフの居住部族が 2 人を名祖としている例が 1 , 存在することによ る（表 $6: * 6 ， * 8 ， * 13) 。$

（10）これらにつき取りあえず述べれば，クフラーン・マズヒジュ等のミフラーフは, その多くがジュシャム諸部族のミフラーフに隣接している。それゆえ，ミフラーフと いう呼称のみが, 部族的背景と関わりなく彼らの地域区分に広がった可能性も考えら れる。アル = ミフラーフ・アッンスライマーニーは, アシール地方紅海沿岸部の大ま かな地方を意味し，1002年に北イエメンのジィヤード朝（Ziyad, 203-409/818-1018) の総督を追放して，自立した人物の名に由来している。ミフラーフ・ジャアファルは, 同じくジィヤード朝のイッブ地方の総督の名に由来するといわれ(諸説あり)，イッブ 及び夕イズ方面の大まかな地方を意味する。いずれにしても，これら 2 ミフラーフは 政治史的背景を持つ特殊なもので, 特定の地域区分の呼称としてのミフラーフとは異 なるものである。

\section{引用文献・資料}

Abū Ghānim, Faḍ ${ }^{c}$ Alì Ahmad

1985 Al-Buniyyah al-Qabaliyyah fĩ al-Yaman; bayna al-Istimrār wa al-Taghayyur, Damascus.

$\mathrm{Akwa}^{\mathrm{c}}$, Muhammad b. ${ }^{\mathrm{c}}$ Alī al-

1987 Hayāt ${ }^{c} \bar{A} l i m$ wa Amīr, Sanª̄̄'.

${ }^{c} A z \bar{a} z \overline{1}$, Muhammad al- and Kurūzah, Hānz

1975 Al-Jumhūriyyah al-c Arabiyyah al-Yamaniyyah; Dirāsāt Tamhĩdiyyah li-Bah th fì al-Tanmiyah al-Idāriyyah, Beirut.

Beeston, A.F.L., Ghul, M.A., Müler, W.W. and Ryckmans, J.

1982 Sabaic Dictionary/Dictionnaire Sabéen, Șanª̄'.

Bosworth, C.E.

1993 "Mikhlāf", ed. by H.A.R. Gibb and others, Encyclopedia of Islam (new edition), Leiden and London, VII, 35.

Hajarī, Muhammad b. Ahmad al-

1984 Majmū $\bar{u}^{c}$ Buldān al-Yaman wa Qabā'il-hāa, ed. by I. ${ }^{\mathrm{c}} \mathrm{A}$. al-Akwa ${ }^{\mathrm{c}}, 2$ vols, $\operatorname{Ṣan}^{c} \bar{a}$.

Hamdānī, al-Ḥasan b. Aḥmad al- 
1986 Kitāb al-Iklīl, 3 vols (I, II and VIII), ed. by M.b. ${ }^{\mathrm{c} A}$. al-Akwac $\operatorname{San}^{\mathrm{c}} \overline{\mathrm{a}}$ '.

1990 Șifah Jazīrah $a l^{-c}$ Arab, ed. by M.b. ${ }^{c} A$ al- Akwa ${ }^{c}, S_{\text {San }}^{c} \bar{a}$.

Ibn Khurdādhbih (Abū al-Qāsim ' ${ }^{\mathrm{C}}$ bayd Allāh b. 'Abdullāh)

1889 Kitāb al-Masālik wa al-Mamālik, ed. by M.J. de Goeje, Leiden.

Ibn al-Mujāwir

1986 Sîfah Bilād al-Yaman wa Makkah wa Bac d al-Hijāz (al-Musammāt Ta'rīkh al-Mustabsir), ed. by O. Lögren, Beirut.

Janadī (al-Kindī), Abū ${ }^{c}$ Abdullāh b. Muhammad al-

1983 Al-Sulūk fì Tabaqāt al-c Ulamā' wa al-Mulūk, I, ed. by M.b. 'A.al-Akwac, $\operatorname{San}^{\mathrm{c}} \overline{\mathrm{a}}$.

Khazrajī, ' Alī b. al-Hasan al-

1983 Al-c Uqüd al-Lu'lu'iyyah fì Ta'rīkh al-Dawlah al-Rasüliyyah, 2 vols, Sanª̀'.

Mad'aj, ${ }^{\mathrm{c}}$ A.M.M. al-

1988 The Yemen in Early Islam 9-233 / 630-847; a Political History, London.

Maqhafī, Ibrāhīm Aḥmad al-

$1988 M u^{c} j a m$ al-Buldān wa al-Qabā'il al-Yamaniyyah, Șan'ā'.

松本弘

1996 「北イエメンにおける地方行政区分と部族」『上智アジア学』, 第14号, 88-105.

1998 「北イエメンにおける地方行政区分の確立一地域区分に関わる伝統と近代一」,

『駒沢史学』, 第52号, 299-330.

Muqaddasī, Shams al-Din Muhammad b. Ahmad al-

1906 Ahsan al-Taqāsìm fì Ma rifah al-Aqālìm, ed. by M.J. de Goeje, Leiden.

Nashwān b. Sacīid al-Himyarī

1981 Muntakhabāt fì Akhbār al-Yaman min Kitāb Shams al- ${ }^{c} U l \bar{u} m$ wa Dawā' Kalām al-c Arab min al-Kulūm, ed. by ${ }^{\mathrm{c}} \mathrm{A}$. Ahmad, Sancā'.

Sayyāghī, Husayn b. Ahmad al- (ed.) (作者不詳)

1984 Safahät Majhülah min Ta'rīkh al-Yaman, Sanª̄'.

Steffen, H.

1979 Population Geography of the Yemen Arab Republic; the Major Findings of the Population and Housing Census of February 1975 and of Supplementary Demographic and Cartographic Surveys, Wiesbaden.

Wilson, R.T.O.

1989 Gazetteer of Historical North-West Yemen, Hildesheim, Zürich and New York.

Yahyā b. al-Husayn b. al-Qāsim

1968 Ghāyah al-Amān̄ fì Akhbār al-Qutr al-Yamān̄̄, ed. by S. ${ }^{c}$ A. ${ }^{c} \bar{A} s h u ̄ r, 2$ vols, Cairo. 


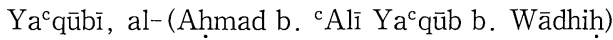

1892 Kitāb al-Buldān, ed. by M.J. de Goeje, Leiden.

Yāqūt (al-Hamawī) , 'A Abdullāh

$1955 M u^{c} j a m$ al-Buldān, ed. by Dār Sādir and Dār Bayrūt, 5 vols, Beirut.

1988 Al-Buldān al-Yamāniyyah ${ }^{c}$ inda Yãqūt al-Hamawì, ed. by I. ${ }^{\mathrm{A}} \mathrm{A} \cdot \mathrm{al}-\mathrm{Akwa}^{\mathrm{c}}$, Beirut and $\operatorname{San}^{\mathrm{c}} \overline{\mathrm{a}}$. 
表 1.SA に記されたミフラーフー覧（10世紀）

[Hamdānī 1990: 92,157,167,181,193-214,222-4,232]

各ミフラーフの位置は現在の地名であり, $\mathrm{N}$ はナーヒヤ, $\mathrm{Q}$ は郡, 括弧内は以下の州名 を表わす。 $\mathrm{SN}=$ サナア州, $\mathrm{SD}=$ サア多州, $\mathrm{HA}$ =ハッジャ州, $\mathrm{MH}=$ ハフウィート州, $\mathrm{MA}=$ マーリブ州, $\mathrm{DH}=$ ダマール州, $\mathrm{BA}=$ バイダー州, $\mathrm{IB}=$ イッブ州, TA=タイズ州, $\mathrm{HD}=$ ホデイダ州。また, 部族に関する括弧内は, 当該部族の系統を表わす。各ミフラー フの位置特定については, SA 及び $\mathrm{MB}$ の記述及び当該箇所に関する編者の注に加え, 各 種の地困や [Maqhafī 1988]，［Steffen 1979］等の資料を援用した。（表 2 も同じ）

1. Banī ${ }^{c} \bar{A} \operatorname{mir}$.

位置: Dhamār (DH) と Radāc (BA)の間.

部族：Kuhlān Madhhij 7 部族, Himyar 3 部族, Saba' 2 部族,

Kuhlān Khath ${ }^{\mathrm{c}}$ am 1 部族, 他10部族（系統不明）

2. Shabwah.

位置：南イエメン

部族：al-Ashbā', al-Ayzūn (Himyar), Șuda', Ruhā'(系統不明)

3. al-Macāfir.

位置：Q.al-Hujariyyah, N.Ṣabir wa al-Mawādim, N.Dimnah al-Khadīr (TA)

部族： al-Ma $-\mathrm{a}^{\mathrm{c}} \mathrm{air}$ 諸部族 (Himyar), Saksak 諸部族(系統不明)

4. al-Sahūul.

位置：Q.Ibb, Q.al-c'Udayn, Q.al-Makhādir, Q.Dhī al-Sufāl(IB), N.Shar ${ }^{c} a b(T A)$

部族：al-Sahūl, $\bar{A} l$ Sharcab, Wuhāzanah, al-Kalāc ${ }^{c}$, 他 (Himyar), al-Tabāciyyūn(Hamdān), Buhayl, al-Mawājid(系統不明)

5. al-c Awd wa Dhī Rucayn.

位置 : Q.al-Nādirah(IB)

部族： al-c Awdiyyūn (Dhū Ru ${ }^{c}$ ayn, Himyar), Banū Mūsā (al-Kalāec, Himyar)

6. Dhī Rữayn.

位置 : N.Yarīm, N.Ba ${ }^{c}$ dān(IB) 部族 : Dhū Ru $u^{c} a y n ~ 4$ 部族以上 (Himyar)

7. Jayshān.

位置: N.Qa $a^{c} \operatorname{tabah}(\mathrm{IB}) \quad$ 部族: Dhu $\mathrm{Ru}^{\mathrm{c}}$ ayn 3 部族 (Himyar)

8. $\operatorname{Rada}^{\mathrm{c}}$ wa Thāt.

位置: Q. $\operatorname{Radā}^{c}(B A), N \cdot \operatorname{al}-\operatorname{Hadā}(D H)$

部族：Kuhlān Madhhij 諸部族, Himyar 諸部族, 他 5 部族以上 (系統不明)

9. Ma'rib.

位置 : Q.Ma'rib, N.Harīb(MA)

部族 : Murād(Kuhlān Madhhij), 他 1 部族(系統不明) 
10. Balad al-Rakb.

位置：N.Wusāb al-Sāfil(DH), N.Hays, N.Jabal Ra's(HD)

部族: $\bar{A} 1$ Abī al-Namr al-Rakbiyyūn(Himyar)

11. Jublān al-c Arkabah.

位置 : N. Wuṣāb al-c $\bar{A} l \bar{l}$ (DH) 部族 : al-Wuṣābiyyūn(Himyar)

12. $N a^{c} m a ̄ n$.

位置 : N.Wuṣāb al-Sāfil (DH) 部族：al-Wuṣābiyyūn(Himyar)

13. Jublān Raymah.

位置: Q. Raymah (SN)

部族 : Nasl Jublān, al-Sarādif, Banū Hayy b. Khawlān(Himyar)

14. Bura ${ }^{\mathrm{c}}$.

位置: N.Bura ${ }^{c}(H D)$ 部族：al-Ṣanābir (Himyar), Hamdān 2 部族

15. Dhamār.

位置 : N.Dhamār (DH) 部族 : ${ }^{c}$ Ans (Kuhlān Madhhij), Himyar 諸部族

16. Alhān wa Muqrī.

位置 : Q.Ānis, N.Maghrib ${ }^{c}$ Ans $(\mathrm{DH})$

部族: (Alhān) : Alhān(Kuhlān), Himyar 諸部族, Hamdān 1 部族, (Muqrī) : Ā1 Muqrī (Himyar)

17. Harāz wa Hawzan.

位置: Q. Harāz (SN) 部族: Harāz, Hawzan(Himyar)

18. Hadūr.

位置 : N.Ban̄̄ Mațar(SN) 部族 : Hadūr, al-Ṣayad, al-Jahādib(Himyar)

19. Aqyān.

位置 : N.Shibām wa Kawkabān(MH), N.Thulā (SN)

部族：Aqyān(Himyar), Hamdān 2 部族以上, 他 6 部族 (系統不明)

20. Dhī Jurah wa Khawlān.

位置 : N.Sanhān, N.Ban̄̄ Hushaysh, N.Bilād al-Rūs, N.Jihānah,

N. Banī Bahlūl(SN)

部族 : Dhū Jurah, Khawlān al-c'Āliyyah(Kuhlān)

21. Șac $\mathrm{dah}$.

位置 : N.S.Sacdah, Q.Khawlān (SD)

部族：Khawlān Quḍācah 2 部族 (Himyar), Hamdān 1 部族,

他 1 部族 (系統不明)

22. Ma'dhin wa Humlān.

位置: N.Hamdān(SN), Q.Hajjahの南部(HA)

部族：(Ma'dhin) : Ma'dhin(Dhū Rucayn, Himyar)

(Humlān, 別名 Mikhlāf Lā $\left.\bar{a}^{c} a h\right) ：$ 記載なし 
23. al-Maclal.

位置: N. Banī Mațar (SN)

部族: Banū al-Ghawth b. Sac d(Himyar)

24. Maytam.

位置 : N.Dhamār の南部(DH) 部族 : Kuhlān Madhhij 諸部族

25. Zabīd.

位置：N.Zabīd(HD) 部族：al-Huṣayb (Himyar)

26. Mawr ${ }^{\mathrm{c} A k k i y y a h . ~}$

位置：Q.al-Luhayyah(HD) 部族：記載なし [ ${ }^{\mathrm{c} A k k(K u h l a ̄ n)] ~}$

27. ${ }^{\mathrm{c}}$ Aththar.

位置：アシール＼cjkstart部族：記載なし

28. Haly.

位置：アシール＼cjkstart部族：記載なし

表 2.MB に記されたミフラーフー覧(13世紀)

[Yāqūt 1955, I: 86, 118, 121, 144, 222, 247, 255, 358, 452, 471, 475-6, 501, 508, 523, 528; II: 70, 74-5, 90, 102, 126, 131, 140, 144, 167, 200, 205, 234, 272, 278-80, 319, 373, 390, 407, 415; III: 32,39, 52, 63, 68, 111, 114-5, 195, 208,211,224-5,229, $265,277,310,327,335,379,397,405-6,464$; IV: 105, 128, 142-3, 146, 161-3, 188, 207, 312, 423, 439, 482; V: 14, 20, 23, 58, 67-70, 102 110, 120, 133, 136, 147, 190, $234-5,253,266,284-5,353,363-5]$

1. Abyan.

位置：南イエメン 部族：Abyan(Himyar al-Humaysa ${ }^{c}$ )

2. al-Ahwar.

位置：南イエメン 部族：記載なし

3. al-Akhrūt.

位置：記載なし 部族：記載なし

4. al-Akhrūj.

位置 : N.al-Haymah al-Dākhiliyyah, N.al-Haymah al-Khārijiyyah(SN)

部族：記載なし [al-Akhrūj, Himyar al-Humaysa ${ }^{c}$ ]

5. Arhab.

位置: N.Arhab(SN) 部族 : Arhab(Bakīl, Hamdān)

6. Aclāq $A n^{c} u m$.

位置：アシール 部族：記載なし

7. Alhān, 別名 Ikhwah Hamdān.

位置 : Q.Ānis (DH) 部族 : Alhān(Kuhlān) 
8. Amlat.

位置：記載なし 部族：記載なし

9. al-Amlūl [al-Amlūk].

位置：N.al-Shicir(IB)

部族：al-Amlūl [al-Amlūk] (Himyar al-Humaysa ${ }^{c}$ )

10. Amūl.

位置：記載なし 部族：記載なし

11. Badr.

位置：N.Qactabah(IB) 部族：記載なし

12. $B a^{c} d a ̄ n$.

位置：N.Ba ${ }^{\mathrm{c}} \mathrm{dān}(\mathrm{IB})$ 部族：記載なし $\left[\mathrm{Ba}^{\mathrm{c}} \mathrm{d}\right.$ ān, Himyar al-Humaysa $\left.{ }^{\mathrm{c}}\right]$

13. Baqarān [Baqirān] .

位置 : N.Banī Matar(SN) 部族：Banū Nujayd [Banū Majīd]（系統不明）

14. Bakīl.

位置：サナア州北部＼cjkstart部族：Bakīl (Hamdān)

15. Banī ${ }^{\mathrm{c}} \overline{\mathrm{A}} \mathrm{mir}$.

位置 : Dhamār $(\mathrm{DH})$ と $\operatorname{Rad} \bar{a}^{\mathrm{c}}(\mathrm{BA})$ の間＼cjkstart部族：記載なし

16. Banū Nujayd.

位置 : N.Mukhā (TA) 部族：Banū Nujayd [Banū Majīd]（系統不明）

17. Bawshān.

位置：記載なし 部族：記載なし

18. Bayhān.

位置：N.Nac mān(MA) 部族：記載なし

19. Baysh.

位置：アシール 部族：記載なし

20. Thāt.

位置: N.Radā $\bar{c}^{\mathrm{c}}(\mathrm{BA})$ 部族 : Dhū Thāt(Himyar)

21. Thujjah.

位置：N.Jiblah(IB) 部族：記載なし [al-Sahūl, Himyar al-Humaysa ${ }^{c}$ ]

22. Jābān.

位置：N.Juban(BA) 部族：記載なし

23. Jublān Raymah.

位置: Q. Raymah $(\mathrm{SN})$ 部族: Jublān (Himyar al-Humaysa ${ }^{c}$ )

24. Jurash.

位置：アシール 部族：Jurash(Himyar al-Humaysa ${ }^{c}$ )

25. Jurayb.

位置：N.Zabīd(HD) 部族：記載なし 
26. al-Jasrah.

位置：記載なし 部族：記載なし

27. $\mathrm{Ju}^{\mathrm{c} f \mathrm{i}}$.

位置：南イエメン 部族 : Juc fī (Kuhlān Madhhij)

28. Janb.

位置 : アシール 部族 : Banū Yazīd 6 部族(Kuhlān Madhhij)

29. Jayshān.

位置: N.Qa $a^{c} \operatorname{tabah}(\mathrm{IB})$ 部族: Jayshān(Himyar al-Humaysa ${ }^{c}$ )

30. Hāzzah Banī Shihāb.

位置：N.Banī Matar (SN) 部族：記載なし

31. Harāz wa Hawzan.

位置：Q. Harāz (SN) 部族：Harāz, Hawzan(Himyar al-Humaysa ${ }^{c}$ )

32. Hadūr.

位置：N.Ban̄̄ Matar(SN) 部族：Hadūr (Himyar al-Humaysa ${ }^{c}$ )

33. al-Haql.

位置：N. Yarīm(IB)

部族：al-Haq1，別名Dhū Qubāb [Qitāb] (Himyar al-Humaysac)

34. Hakam.

位置 : アシール 部族 : al-Hakam b. Sacd al-cAsīrah (Kụlān Madhhij)

35. Hawshab.

位置：南イエメン 部族：記載なし

36. Khashab.

位置 : Sirwāh と Arhab の間 (SN) 部族：Dhū Khashab(系統不明)

37. Khunās [Hufāsh] .

位置：N.Hufāsh $(\mathrm{MH})$ 部族：記載なし

38. Khawlān.

位置：Q.Khawlān (SD) 部族：Khawlān Quḍa $\bar{a}^{\mathrm{c}} \mathrm{ah}$ (Himyar Quḍa $\overline{\mathrm{C}}^{\mathrm{c}} \mathrm{ah}$ )

39. Khaywān.

位置：N.Hūth $(\mathrm{SN}) \quad$ 部族：記載なし

40. al-Ruhābah.

位置：サナア州北部＼cjkstart部族：Hamdān 諸部族

41. $\operatorname{Ruda}^{\mathrm{c}}$.

位置：アシール＼cjkstart部族：Khawlān al-c ${ }^{c} \bar{A}$ liyyah(Kuhlān)

42. Rucayn.

位置：N. Yarīm, Q.al-Nādirah(IB)

部族: Dhū Rucayn (Himyar al-Humaysa ${ }^{c}$ )

43. al-Rakb. 
位置：N.Wuṣāb al-Sāfil(DH), N. Hays, N.Jabal Ra's(HD)

部族：記載なし

44. Rayhāan.

位置 : N.Banī Ḍabyān(MA)

部族: Banū Ẓabyān [Ḍabyan] (Khawlān al-c'Āliyyah, Kuhlān)

45. Raymān.

位置：N.Ba ${ }^{c} \mathrm{da} n(\mathrm{IB})$

部族：記載なし [Raymān(Himyar al-Humaysa ${ }^{\mathrm{c}}$ )]

46. Raymah al-Ashābit.

位置：Q.Raymah $(\mathrm{SN})$ 部族：記載なし

47. al-Suhūil [Sahūil] .

位置：Q.Ibb, Q.al-Makhādir, Q.al-c Udayn(IB)

部族：al-Sahūl (Himyar al-Humaysa ${ }^{\mathrm{c}}$ )

48. Sarhah.

位置：記載なし 部族：記載なし

49. al-Sirr.

位置：N.Banī Hushaysh(SN) 部族：記載なし

50. al-Sakāsik.

位置：Q. Tacizz (TA) 部族：al-Saksak (Kuhlān)

51. Sinhān.

位置：アシール＼cjkstart部族 : Sinhān(Janb, Himyar Qudāacah)

52. Sūb.

位置：記載なし 部族：記載なし

53. Shākil.

位置：N.Dhībīn(SN) 部族：Shākil Arhab(Bakīl, Hamdān)

54. Shahāt.

位置：記載なし 部族：記載なし

55. Shar ${ }^{c} a b$.

位置：N.Sharcab (TA)

部族：記載なし [Sharcab (Himyar al-Humaysa $\left.\left.{ }^{\mathrm{c}}\right)\right]$

56. Shayyabah [Shībah].

位置：Q.al-c Udayn(IB) 部族：記載なし

57. Sudā'.

位置：Q. Bayḍ̄ā'(BA) 部族：Șudā'(Kuhlān Madhhij)

58. al-Șadif.

位置：南イエメン 部族：記載なし

59. $\mathrm{Sa}^{\mathrm{c}} \mathrm{b}$. 
位置：N.al-Hadā $(\mathrm{DH})$ 部族 $: \mathrm{Sa}^{\mathrm{c}} \mathrm{b}$ (系統不明)

60. $\mathrm{Sa}^{\mathrm{c}} \mathrm{dah}$.

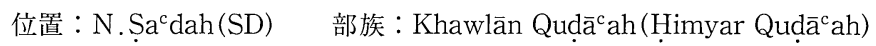

61. Dankān.

位置 : アシール 部族 : Banū ${ }^{\mathrm{c}} \mathrm{Amr}$ b. Kilāb(系統不明)

62. al-c Urf.

位置：記載なし 部族：記載なし

63. 'Ișār.

位置：記載なし 部族：記載なし

64. ${ }^{\mathrm{c}} \mathrm{Akk}$.

位置: Q.al-Luhayyah, Q.al-Hudaydah, Q.Bājil, Q.Bayt al-Faqīh(HD)

部族 : ${ }^{\mathrm{c}} \mathrm{Akk}$ (Kuhlān)

65. ${ }^{\mathrm{c}}$ Alq.

位置：記載なし 部族：記載なし

66. ${ }^{\mathrm{c}}$ Ans.

位置 : N.Dhamār $(\mathrm{DH}) \quad$ 部族: ${ }^{\mathrm{c}}$ Ans (Kuhlān Madhhij)

67. ${ }^{\mathrm{c}}$ Unnah [ ${ }^{\mathrm{c}}$ Annah].

位置 : N.al-c Udayn(IB)

部族：記載なし $\left[{ }^{\mathrm{c}} \mathrm{Annah}\left(\mathrm{al}-\mathrm{Kal} \bar{a}^{\mathrm{c}}\right.\right.$, Himyar al-Humaysa $\left.\left.{ }^{\mathrm{c}}\right)\right]$

68. Ghudar.

位置：記載なし 部族：記載なし

69. Ghutayf.

位置：Q.Ma'rib(MA) 部族: Murād ' Asīrah al-Ṣahābī (Kuhlān Madhhịi)

70. Fāwah.

位置：アシール 部族：記載なし

71. Qudam.

位置 : Q. Hajjahの南部 (HA) 部族：記載なし

72. Qayzān.

位置：Q.Yarim (IB) 部族：記載なし

73. Kuhlān [Kaḥlān] .

位置: Q.al-Nādirah (IB)

部族: Kahlān Dhī Ru'ayn(Himyar al-Humaysac ${ }^{c}$ )

74. Kindah.

位置：南イエメン 部族：Kindah(系統不明)

75. Lahj.

位置：南イエメン 部族：Lahj(Himyar al-Humaysa ${ }^{c}$ )

76. Lafwān. 
位置：記載なし 部族：記載なし

77. al-Lumciyyah.

位置：記載なし 部族：記載なし

78. Majnah [Mujjayh].

位置 : Q.Harāz $(\mathrm{SN})$ 部族：記載なし [Harāz $\left(\right.$ Himyar al-Humaysa $\left.\left.^{c}\right)\right]$

79. Shabwah.

位置：記載なし 部族：al-Ashbā', al-Āyzūn(系統不明)

80. al-Ma ${ }^{\mathrm{c}} \overline{\mathrm{a}}$ fir .

位置 : Q.al-Hujariyyah (TA) 部族 : al-Macāirir(Kuhlān)

81. al-Yahṣubayn [al-Yahṣibayn] .

位置 : Q. Yarim (IB), N. ${ }^{c} U$ tumah (DH)

部族: Banū Yahṣub [Yahṣib] (Himyar al-Humaysa ${ }^{c}$ )

82. al-c Awd.

位置 : N.al-Nādirah(IB)

部族: al- ${ }^{\mathrm{c}}$ Awdiyyūn $\left(\mathrm{Dhu}\right.$ Rucayn, Himyar al-Humaysa $\left.{ }^{\mathrm{c}}\right)$, Himyar 諸部族

83. Maytham [Maytam].

位置：N.Dhamār の南部 $(\mathrm{DH})$ 部族：記載なし

84. $\operatorname{Rud}^{\mathrm{c}}\left[\operatorname{Rad} \bar{a}^{\mathrm{c}}\right]$ wa Thāt.

位置: Q. Radā $\bar{a}^{c}(B A)$ 部族 : Radman, Kawmān(系統不明)

85. Ma'rib.

位置：Q.Ma'rib (MA) 部族：記載なし

86. Dhamār.

位置 : N.Dhamār $(\mathrm{DH})$

部族：Dhamār b. Yaḥ̣ub [Yahṣib] (Himyar al-Humaysac ${ }^{c}$ ), Himyar 諸部族, Anfār of al-Abnā' (系統不明), ${ }^{\mathrm{c} A n s}$ 諸部族 (Kuhlān Madhhij)

87. Ma'dhin.

位置: N.Hamdān (SN) 部族 : $\bar{A} l$ Dhū Rucayn(Himyar al-Humaysa ${ }^{c}$ )

88. Aqyān.

位置：N.Thulā (SN), N.Shibām wa Kawkabān (MH)

部族: Shibām Aqyān (Himyar al-Humaysac)

89. Dhī Jurrah wa Khawlān.

位置：N.Sanhān, N. Bilād al-Rūs, N. Banī Ḥushaysh, N.Jihānah, N. Ban̄̄ Bahlūl(SN)

部族: Dhū Jurrah, Khawlān al-c ${ }^{c}$ Aliyyah (Kuhlān)

90. Hamdān.

位置 : サナア州北部 部族 : Hamdān 諸部族

91. Muqrā [Muqrīi]. 
位置 : N.Maghrib ${ }^{\mathrm{c} A n s,}$ Q.Ānis (DH)

部族：Muqrī (Himyar al-Humaysa ${ }^{\mathrm{c}}$ )

92. Jahrān.

位置：N.Mac ${ }^{c} \operatorname{bar}(\mathrm{DH})$ 部族：Jahrān(Himyar al-Humaysa ${ }^{\mathrm{c}}$ )

93. al-Bawn.

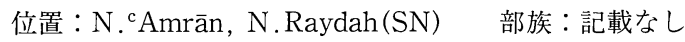

94. Wādicah.

位置：アシール 部族：Wādicah b. ${ }^{c} A m r ~ b . N a s h i j($ 采統不明)

95. Zubayd.

位置：N.Dhamār (DH) 部族：Zubayd (Kuhlān Madhhij)

96. Nahd.

位置：記載なし 部族：記載なし

97. Shihāb.

位置：N.Ban̄̄ Mațar(SN) 部族：Shihāb (Himyar Quḍācah)

98. Yām.

位置 : アシール 部族 : Hāāhid 諸部族 (Hamdān)

99. Milhān.

位置：N.Milhān(MH) 部族：Milhān(Himyar al-Humaysa ${ }^{c}$ )

100. Mahrah.

位置：南イエメン＼cjkstart部族：Mahrah(Himyar Qudā̄ah)

101. Mihsāa .

位置：Q.Ḥarāz (SN)＼cjkstart部族：記載なし [Ḥaāz (Himyar al-Humaysac $\left.{ }^{\mathrm{C}}\right)$ ]

102. Nāfic .

位置：南イエメン 部族：記載なし

103. Najrān.

位置：アシール 部族：Najrān b. Zaydān b. Saba'(系統不明)

104. Nasafān.

位置 : Q. $\operatorname{Yar}(\mathrm{m}(\mathrm{IB}) \quad$ 部族：記載なし

105. Wãdị .

位置：N.Banī Matar(SN) 部族：記載なし [Himyar al-Humaysa ${ }^{c}$ ]

106. Wuhāzah.

位置 : N.Hubaysh(IB) 部族：Uhāzah [Wuhāzah] (Himyar al-Humaysac ${ }^{c}$ )

107. Wadācah.

位置：N.Hamdān(SN)

部族：記載なし [Dhū Ma'dhin(Himyar al-Humaysac $)$ ]

108. Hayyah.

位置：記載なし 部族：記載なし 
109. Marhad.

位置：記載なし 部族：記載なし

110. Marmal.

位置：N.Hamdān (SN) 部族：記載なし

111. al-Mazdara ${ }^{\mathrm{c}}$.

位置：記載なし 部族：記載なし

112. al-Mashriq.

位置：al-Bayḍā' (BA) と Ma'rib(MA)の間＼cjkstart部族：記載なし

113. al-Mașānic ${ }^{\text {. }}$

位置 : N.Thulā (SN) 部族 : $\bar{A} 1$ Dhū Hiwāl(Himyar al-Humaysa ${ }^{c}$ )

114. Matārib.

位置：記載なし 部族：記載なし

115. al-Salif.

位置：記載なし 部族：記載なし

116. Wahdah.

位置：記載なし 部族：記載なし

117. Harāz .

位置: Q.Zabīd(HD) 部族: Harāz (Himyar al-Humaysa ${ }^{c}$ )

118. Hadūr.

位置: Q.Zabīd(HD) 部族: Hadūr (Himyar al-Humaysa ${ }^{c}$ )

119. Aqyān.

位置：記載なし

部族：Aqyān b. Saba' b. Ya crub b. Qahțān(系統不明)

表 3.YQに記された北イエメンの地域区分（1940年代）

[Hajarī 1984, I: 21-2, 31-51, 64-5, 115, 119-24, 154, 233-9, 242-4, 246, 252-5, 259, 305, 346-7, 360, 378-9; II: 420, 422, 450, 559-60, 576-7, 590-3, 656, 691-2, 694,727-8，746，769-71，779-80，792-6]。(表 4 も同じ)

括弧内は，ナーヒヤ・レベルの地域区分に関するナーヒヤではない呼称。

suds ( 6 分の 1 ), rubc ( 4 分の 1 ), thumn ( 8 分の 1 ) qism (区分), maktab (事務所), bilād (土地), $\operatorname{dir}(?)$ は, ウズラ・レベルの地域区分に関するウズラではない呼称。

サナア San'ā' 州

(郡なし)

$$
\begin{aligned}
& \text { ナーヒヤ : Banī al-Hārith —6 suds } \\
& \text { Hamdān Șan'ầ —4 } \mathrm{rub}^{\mathrm{c}} \\
& \text { al-Bustān —7 ミフラーフ } \\
& \text { Șanhān }
\end{aligned}
$$


Bilād al-Rūs wa Banī Bahlūl

Banī Hushaysh wa Nihm

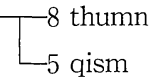

Barat

Arhab -15 qism

Thulā

Sufyān

al-Hadā —-13 ミフラーフ

${ }^{c}$ Utumah —-5 ミフラーフー67 ウズラ*1

Wuṣāb al-c Ầ

Wuṣāb al-Sāfil - $\left[\begin{array}{l}1 \text { ミフラーフ -4 ウズラ } \\ -15 \text { ウズラ*3 }\end{array}\right.$

$\mathrm{Ma}^{\mathrm{c}} \mathrm{rib}$

Harīb

Khawlān al-c'Alliyyah

al-Jawf

${ }^{\mathrm{c} A m r a ̄ n}$ 郡

'Iyāl Surayh —6 maktab

Raydah

Dhībīn

al-Sawdah

(ビラード) Jabal 'Iyāl Yazīd

(ビラード) Banī ${ }^{\mathrm{c}} \mathrm{Abd}$

Zulaymah

Harāz 郡

(呼称なし) Harāz 一14 ミフラーフ

Sac fān

al-Haymah al-Dākhiliyyah

al-Haymah al-Khārijiyyah $\left[\begin{array}{l}1 \text { ミフラーフ } \\ -2 \text { ウズラ*4 }\end{array}\right.$

Șa ${ }^{c}$ dah 郡

Sahār

Jamā $\bar{c}^{\mathrm{a}} \mathrm{h}$

Khawlān

Rāzih

Hamdān

Raymah 郡

$$
\begin{array}{ll}
\text { (アウマール) } & \text { Raymah —-20 ウズラ*3 } \\
& \text { al-Salafiyyah —-17 ウズラ*3 }
\end{array}
$$

Kusmah—8 ウズラ*3

Bilād al-Ta $a^{\mathrm{c}} \bar{a} m — 8$ ウズラ*3 
Hūth 郡

al-Mahwìt 郡

al-Ṭawilah 郡

Ānis 郡

Dhamār 郡

$\operatorname{Rada\overline {a}^{c}}$ 郡

Bayḍā’ 郡

イッブ Ibb 州

Ibb 郡

Yarīm
al-Jacfar —-12 ウズラ*3

al-Qufl

al-Ahnūm

Ban̄ ${ }^{\mathrm{c}}$ Arjalah

(ビラード) al-Mahwit —-6 ウズラ*4

(呼称なし) Khabt al-Mahwit

(ビラード) Sārì —2 ウズラ* 4

Hufāsh —1 ウズラ*4

Milhān

Banī Sacd

Shibām wa Kawkabān —4 ウズラ*3

(ビラード) al-Shāhidhiyyah —7 ウズラ*4

Jahrān —9 ミフラーフ

(ビラード) ${ }^{\mathrm{c} A n s}$ — 12 ミフラーフ

Maghrib 'Ans — 5 ウズラ*3

(ミフラーフ ) al-c Arsh

(ミフラーフ) al-Riyāshiyyah — $4 \mathrm{rub}^{\mathrm{c}}$

(ミフラーフ) al-Hubayshiyyah

(ミフラーフ) Șabāh

Juban

al-Sawwādiyyah

(ビラード) Qayfah

(呼称なし) Damt

(呼称なし) Radmān
ナーヒヤ：Jiblah —14 ウズラ*3

al-Makhādir —-9 ウズラ*3

Hubaysh —27 ウズラ*3

(ミフラーフ) al-Shawāfī —

(ミフラーフ) $\mathrm{Ba}^{\mathrm{c}} \mathrm{dān} — 20$ ウズラ

(ビラード) Yarìm—13 ウズラ*3

(ビラード) Khubān —11 ウズラ*3

al-Nādirah—3 ミーフラーフー-31 ウズラ*5

Qa ${ }^{\mathrm{c} t a b a h}$-1 ミフラーフー3 ウズラ

Dhī al-Sufāl $L_{-18 \text { ウズラ }}^{1 \text { ミフラーフ—8 ウズラ }}$ 
al-c Udayn 郡

ハッジャ Hajjah 州

(郡なし)

Mìdī 郡

Hajūr 郡

タイズ Tacizz 州

Tacizz 郡

al-Hujariyyah 郡
al-Sabrah —13 ウズラ*3

Shalif —1 ミフラーフ

al-Mudhaykhirah —-24 ウズラ*3

ナーヒヤ : Zufayl Hajjah

$$
\begin{aligned}
& \text { (ビラード) Hajjah—4 ウズラ*4 } \\
& \text { Maswar al-Mantāb —9 ウズラ*4 } \\
& \text { Banī al-c Awwām wa Lă } \bar{a}^{\mathrm{c}} \mathrm{ah} \\
& \text { al-Shaghādirah wa Najrah } \\
& \text { Banì Qays }
\end{aligned}
$$

${ }^{c} \mathrm{Abs}$

Harad

al-Mahābishah

$\mathrm{Ku}^{\mathrm{c}}$ aydinah

Aslam

Kushar

Jabal al-Sharq

Washhah

Shamr

al-Sāhil[al-Shāhil]

ナーヒヤ : Șabir —15 ウズラ*3

Sharcab-32 ウズラ*3

Maqbanah

al-Qabbaytah

Jabal Habashī $L_{2}^{11 \text { ウズラ*3 }}$

al-Maqātirah

(ミフラーフ) Dhabhān

(ミフラーフ) Sāmic

(ミフラーフ) Banī Yūsif 


$$
\begin{aligned}
& \text { (ミフラーフ) al-Ṣalū } \\
& \text { (ミフラーフ) Qadas } \\
& \text { (ミフラーフ }) \text { al-Salū } \\
& \text { (ミフラーフ) al-Zacāāzic }
\end{aligned}
$$

Māwiyah 郡 Khadī —-3 ウズラ*3

al-Mukhā 郡 al-Ḥushā-4 ウ ウズラ*4

$$
\text { Mawza }^{c}
$$

(ビラード) al-Ahmūl

(ビラード) Jumªh

(ビラード) ${ }^{c}$ Awāsiqah

(ビラード) Azbūd

(呼称なし) Mushālihah

(呼称なし) Zahāwī

(呼称なし) al-Wāziciyyah

(呼称なし) Bāb al-Mandib その他

ホデイダ al-Hudaydah 州

$$
\begin{aligned}
& \text { Bājil 郡 } \\
& \text { ナーヒヤ： } \text { Bura }^{\mathrm{c}} \longrightarrow 6 \text { ウズラ* } 3 \\
& \text { al-Hujaylah } \\
& \text { al-Luhayyah 郡 } \\
& \text { (ビラード ) al-Zacliyyah }\left[\begin{array}{l}
3 \text { rubc } \\
-3 \mathrm{dir}
\end{array}\right. \\
& \text { (ビラード) al-Bucjiyyah }-4 \mathrm{rub}^{\mathrm{c}} \\
& \text { (ビラード) Banī Jāmic — } 4 \mathrm{rub}^{\mathrm{c}} \\
& \text { (ビラード) al-Wācizăt wa al-Khasm } \\
& \text { (呼称なし) al-Zuhrah } \\
& \text { al-Zaydiyyah 郡 （ビラード） al-Jarābih } \\
& \text { (ビラード) al-Hashābirah } \\
& \text { (ビラード) Salīl } \\
& \text { その他 } \\
& \text { (ビラード) al-Zarā’̄ịq } \\
& \text { (ビラード) al-Marāwicah } \\
& \text { (ビラード) al-Mansūriyyah }
\end{aligned}
$$


(呼称なし) al-Salāmah

(呼称なし) al-Tikaytā

(呼称なし) al-Rakab

(呼称なし) al-Ma ${ }^{\mathrm{c}} \bar{a}$ șilah

*1 5つのミフラーフそれぞれに，13，9，12，17，16のウズラが存在する。

*2 8つのミフラーフそれぞれに，10，8，9，8，14，3，6，6のウズラが存在する。

*3 SA に記されたミフラーフの地理的範囲と重なるウズラ。

*4 SA または YQに記されたミフラーフの地理的範囲と重ならないウズラ。

*5 3つのミフラーフそれぞれに，10，10，11のウズラが存在する。

表 4. YQ に記されたミフラーフ及びウズラと部族との関係

ナーヒヤのミフラーフはウズラ・レベル，郡のミフラーフはナーヒヤ・レベルの地域区 分。

ヒムヤル・アル = フマイサア

ナーヒヤ al-Bustān（サナア州）の 5 ミフラーフ（ウズラなし）(Hadūr 部族）

ナーヒヤ Wuṣāb al-c'Âlī 及びナーヒヤ Wuṣāb al-Sāfil (サナア州) の 9 ミフラーフ (68

ウズラ） (Jublān Wuṣāb 部族)

ナーヒヤ Harāz（サナア州）の14ミフラーフ（ウズラなし）（Harāz 部族）

ナーヒヤ al-Nādirah（イッブ州）の 3 ミフラーフ (31ウズラ） (Ruc ayn 部族)

ナーヒヤ $\mathrm{Qa}^{\mathrm{c}}$ țabah (イッブ州) の 1 ミフラーフ（ 3 ウズラ） (Rucayn 部族)

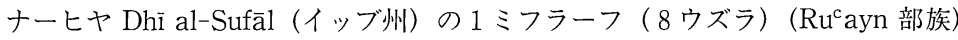

ヒムヤル・クダーア

ナーヒヤ al-Bustān（サナア州）のミフラーフ Banī Shihāb（ウズラなし）

クフラーン・マズヒジュ

ナーヒヤ al-Hadā (サナア州) の13ミフラーフ (ウズラなし) (Hadā b. Murād 部族)

ナーヒヤ ${ }^{\mathrm{c} A n s}$ (サナア州) の12ミフラーフ (ウズラなし) ( ${ }^{\mathrm{c} A n s}$ 部族)

ハムダーン (バキール)

ナーヒヤ al-Bustān（サナア州）のミフラーフ al-Rā $\bar{c}^{-}$(ウズラなし)

その他のクフラーン

al-Hujariyyah 郡 (タイズ州) の 7 ミフラーフ (ウズラなし)

部族の記載なし

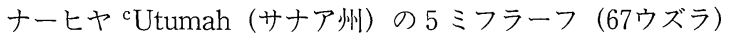

ナーヒヤ al-Haymah al-Khārijiyyah（サナア州）の 1 ミフラーフ（ウズラなし）

ナーヒヤ Jahrān（サナア州）の 9 ミフラーフ（ウズラなし）

$\operatorname{Rad} \bar{a}^{\mathrm{c}}$ 郡 (サナア州) の 4 ミフラーフ (ウズラなし)

Ibb 郡（イッブ州）の 2 ミフラーフ (25ウズラ)

ナーヒヤ Shalif (イッブ州) の 1 ミフラーフ (ウズラなし) 
表 5. KI に記された部族の系譜と SAに記されたミフラーフの関係

[Hamdānī 1986, II:31-2, 67, 107-19, 146, 154, 165, 189, 223-5, 227-31, 233, 243-4, 257-8]

“||”は,系譜の省略を表わす。(表6も同じ)

${ }^{\mathrm{c}}$ Abd al-Shams b. Wā'ilah b. al-Gawth b. Qațan b. ${ }^{\mathrm{c} A r i ̄ b ~ b . ~}$

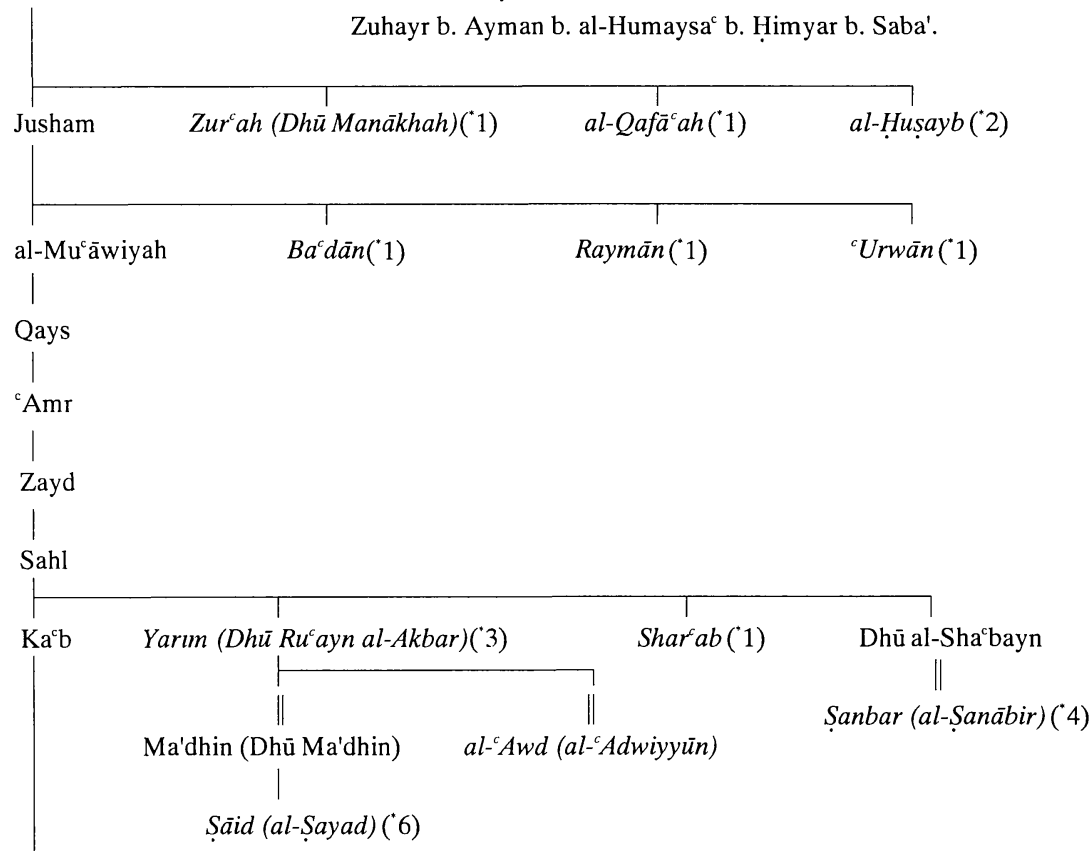

Saba' Aṣghar

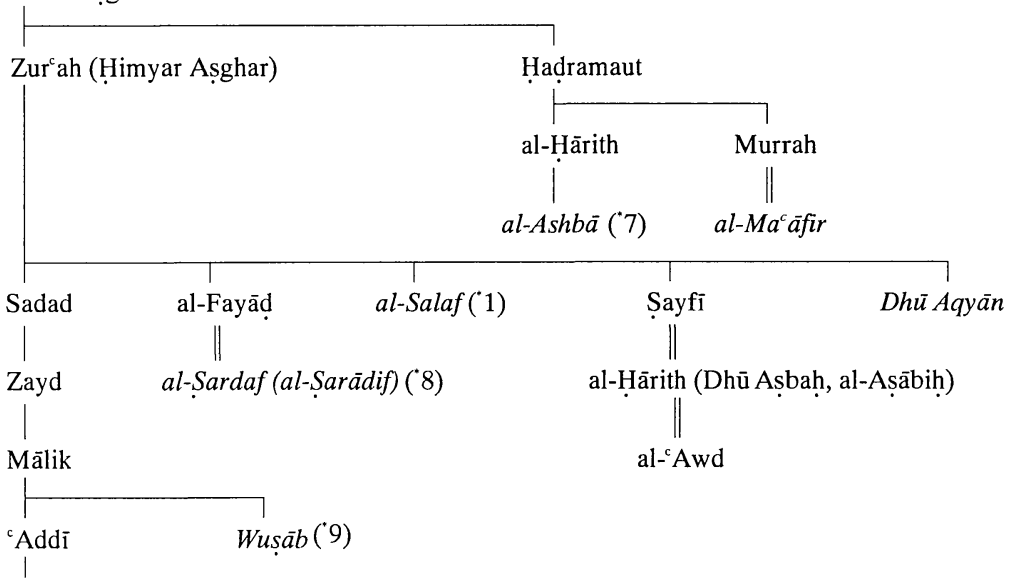




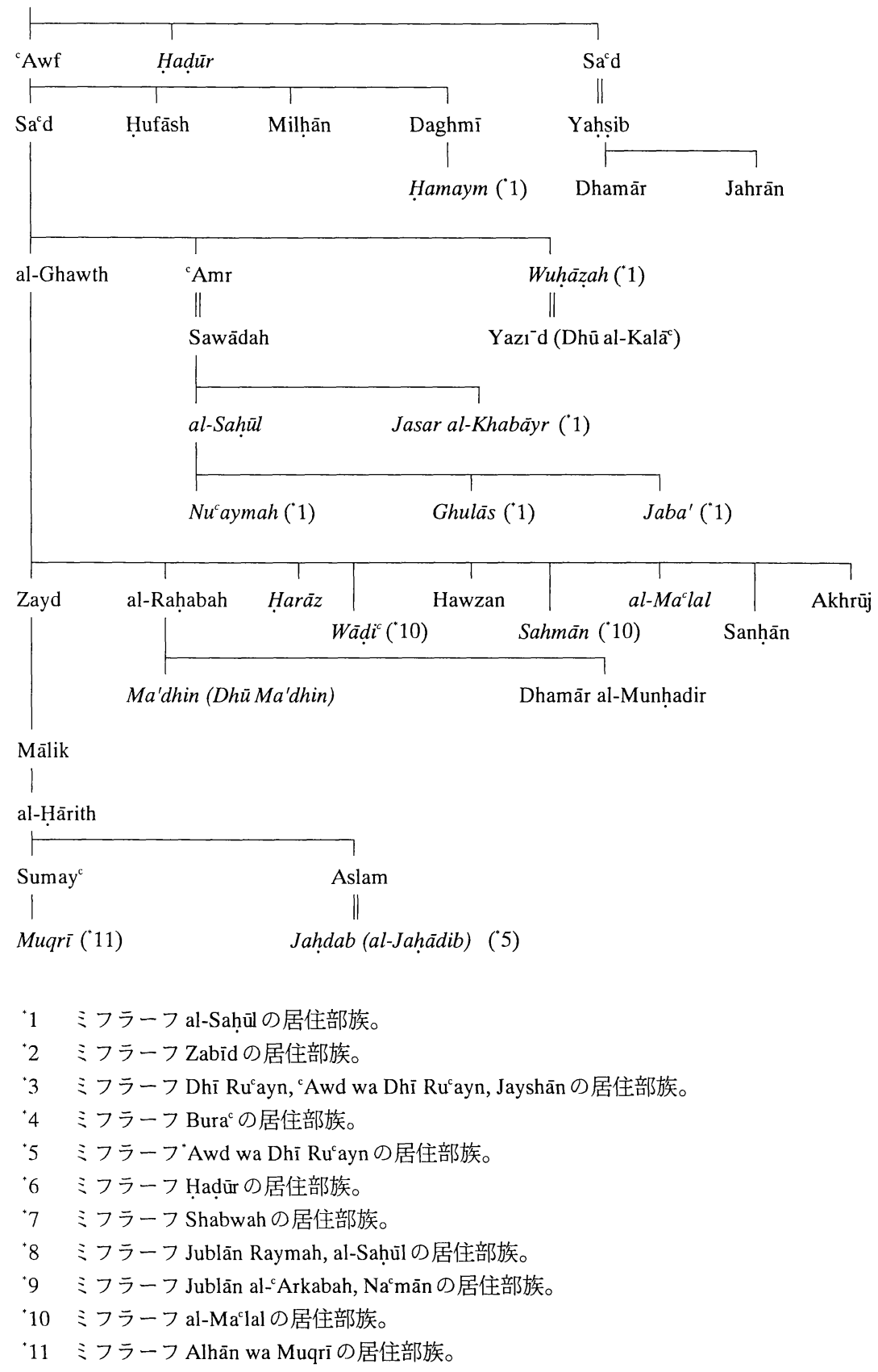


表 6. MBに記された部族の系譜とミフラーフの関係

[Yāqūt 1955, I:86, 144, 247, 255, 475-6; II:102, 126, 144, 167, 200, 234, 272, 278-9, 280, 407; III:52, 195, 224-5, 229, 265, 397; IV:142, 161; V:14, 67, 68-70, 136, 190, 234, 266, 363] Saba'

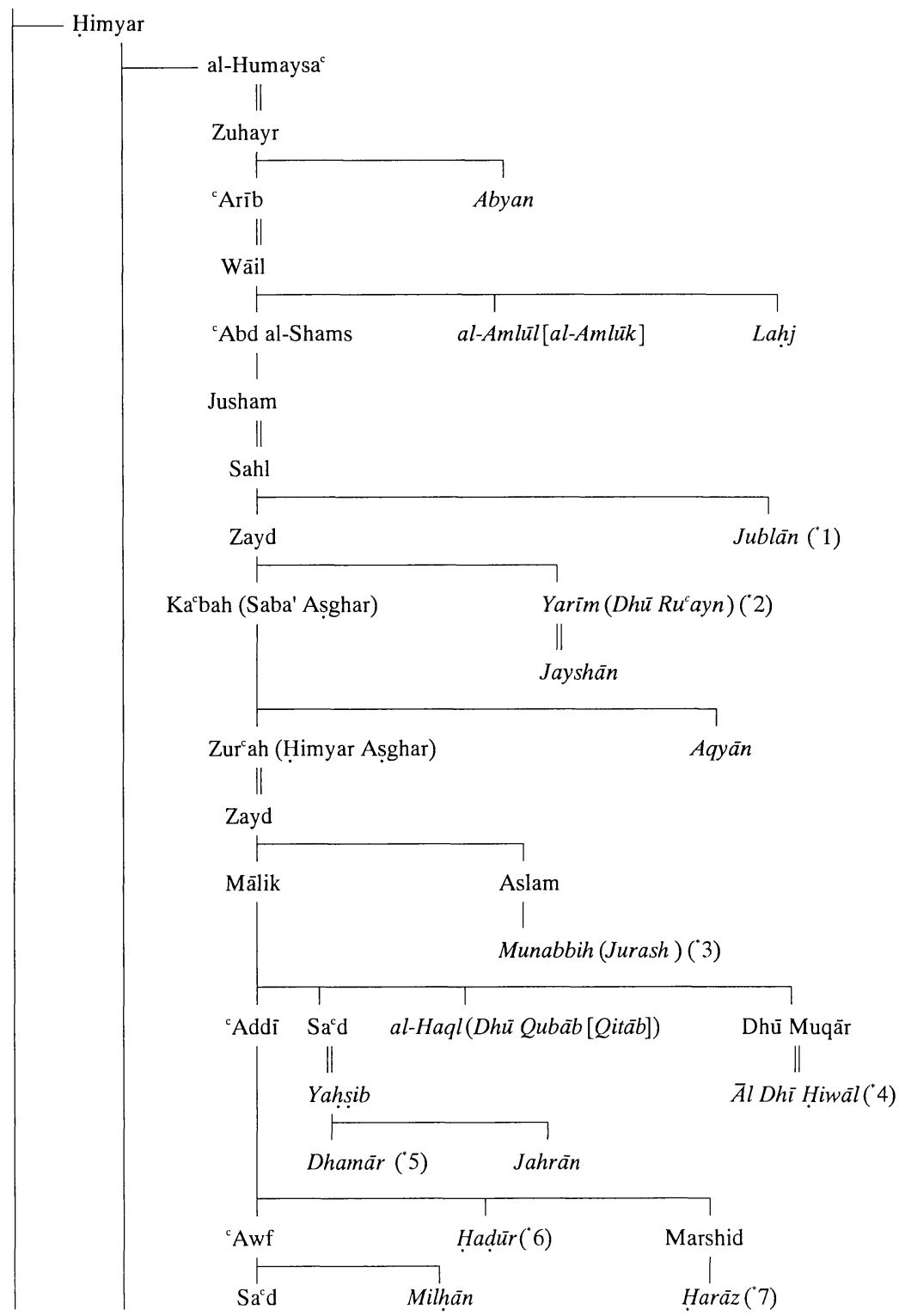




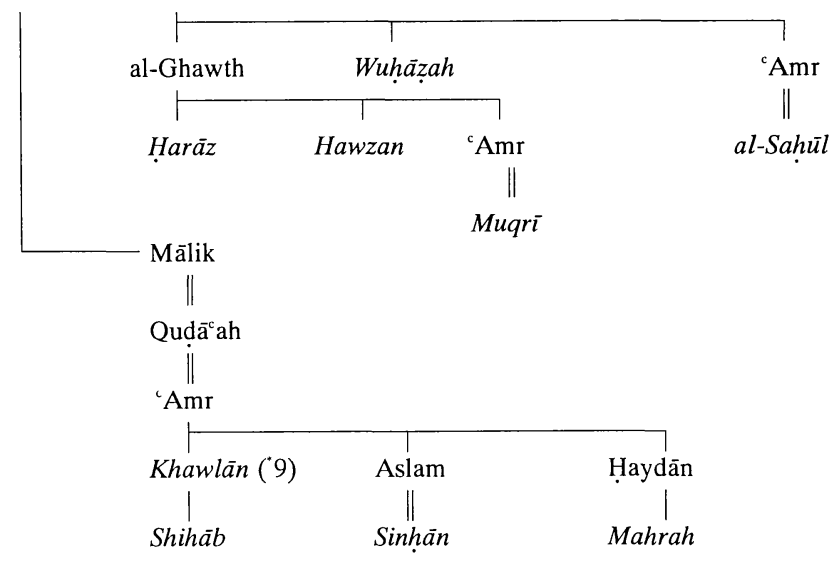

Kuhlān

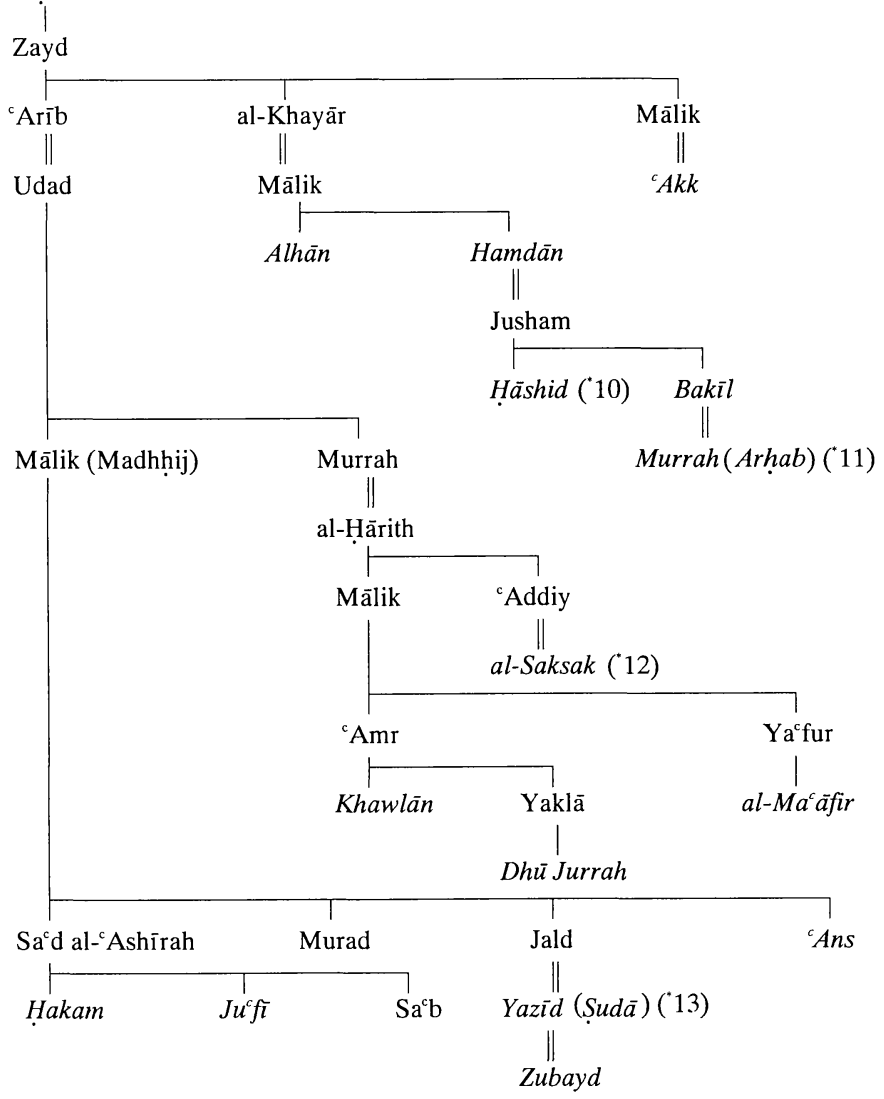


*1 ミフラーフ Jublān Raymah の居住部族。

·2 ミフラーフ Rucayn, Kaḥlān, al- ${ }^{c} A w d, M a ' d h i n$ の居住部族。

3 ミフラーフ Jurash の居住部族。

4 ミフラーフ al-Mạsānic の居住部族。

5 ミ ミフラーフ Dhamārの居住部族だが，このミフラーフはヒムヤル・アル＝フマイサ ア，クフラーン・マズヒジュ等の混住ミフラーフ。

“6 Haḍūr 部族は，部族と同名の 2 つの フラーフ (現サナア州とホデイダ州)に居住。

"7 ミフラーフ Harāz (現ホデイダ州) の居住部族。

'8 ミフラーフ Harāz wa Hawzan (現サナア州) の居住部族。

"9 ミフラーフ Khawlān, Șacdah の居住部族。

10 ミフラーフ Yām の居住部族。

'11 ミフラーフArhabの居住部族。

'12 ミフラーフ al-Sakāsik の居住部族。

'13 ミフラーフ Șudā', Janbの居住部族。 

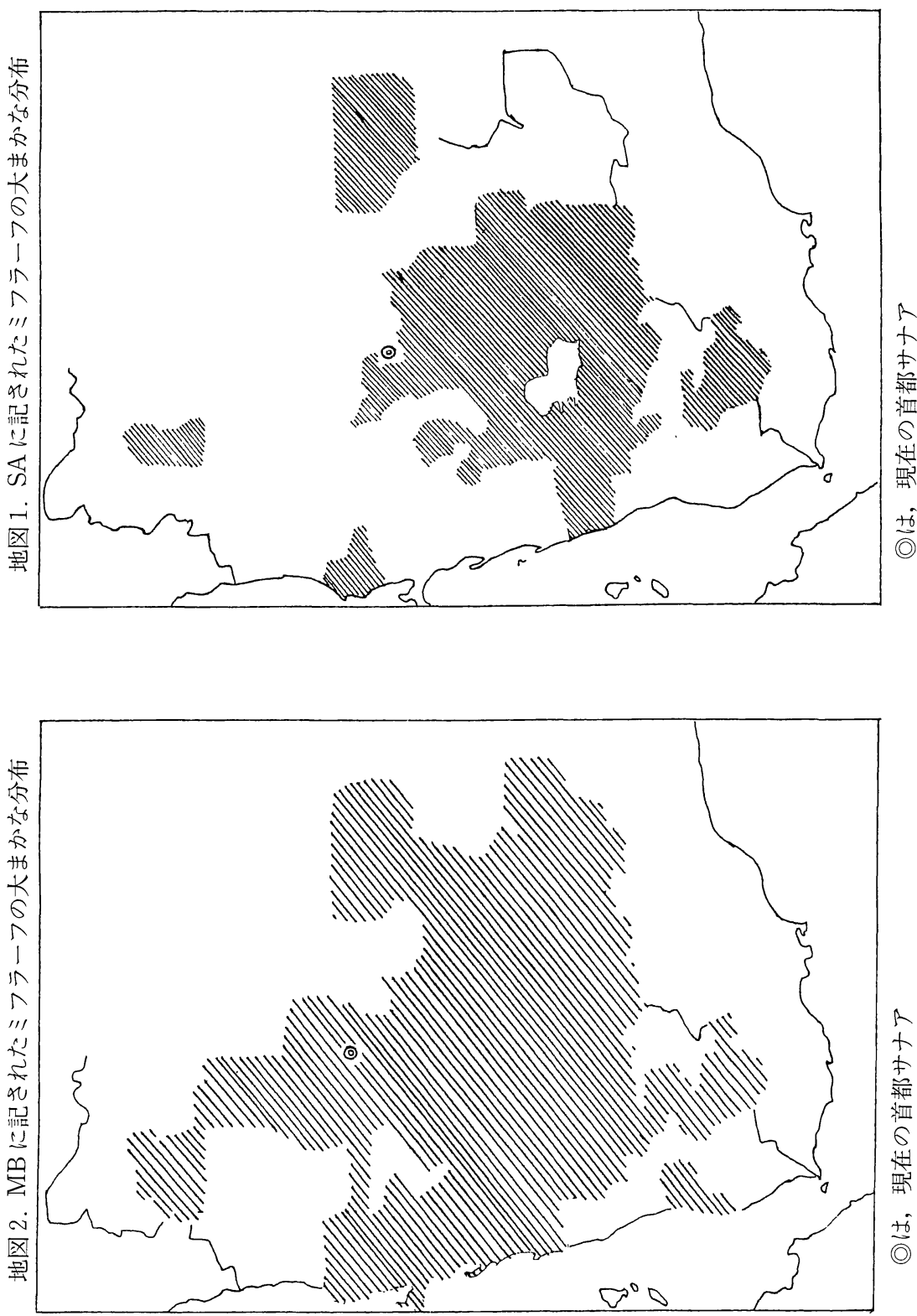

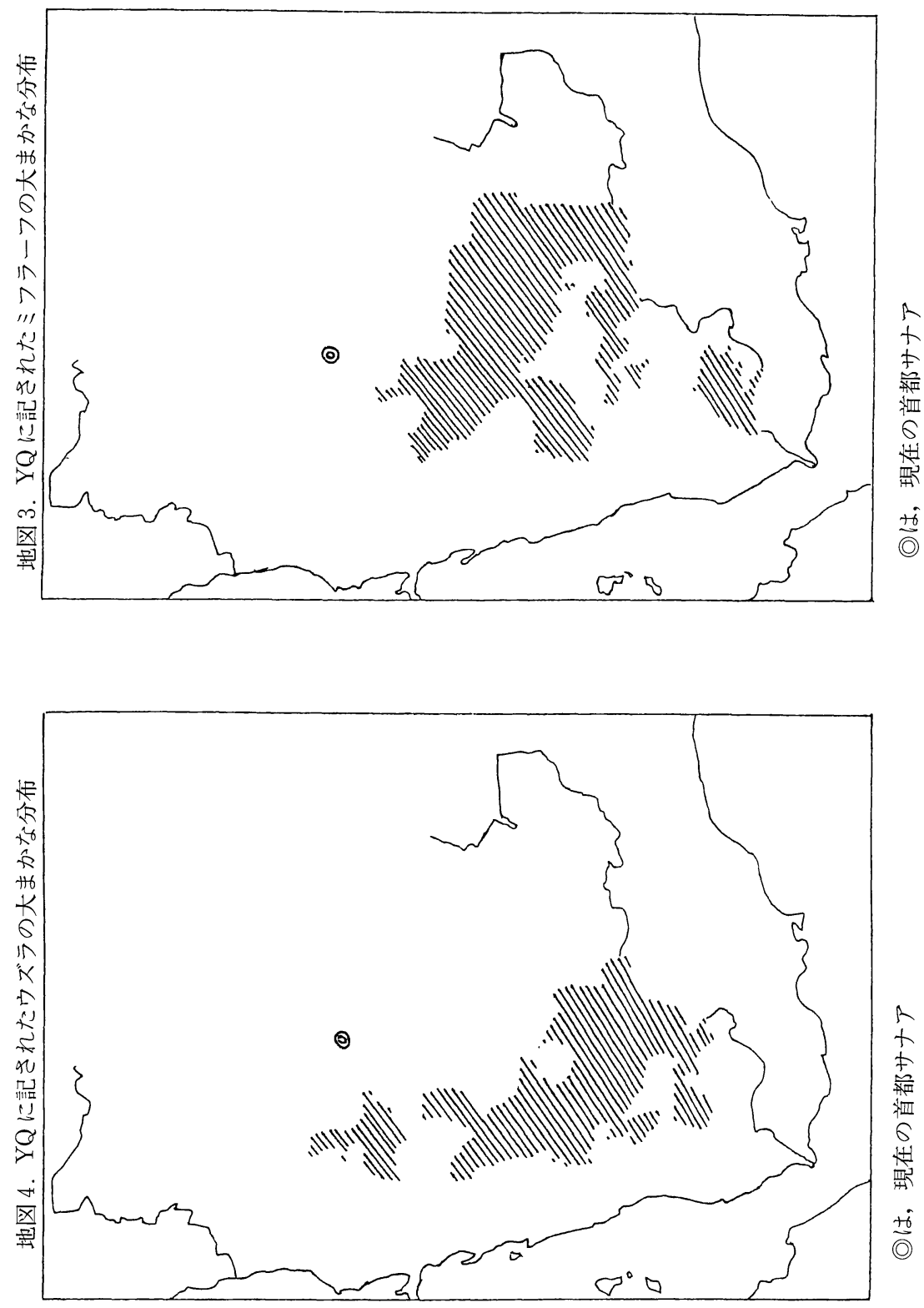
地図 5. 現在の北イエメン各州（1984年以降）

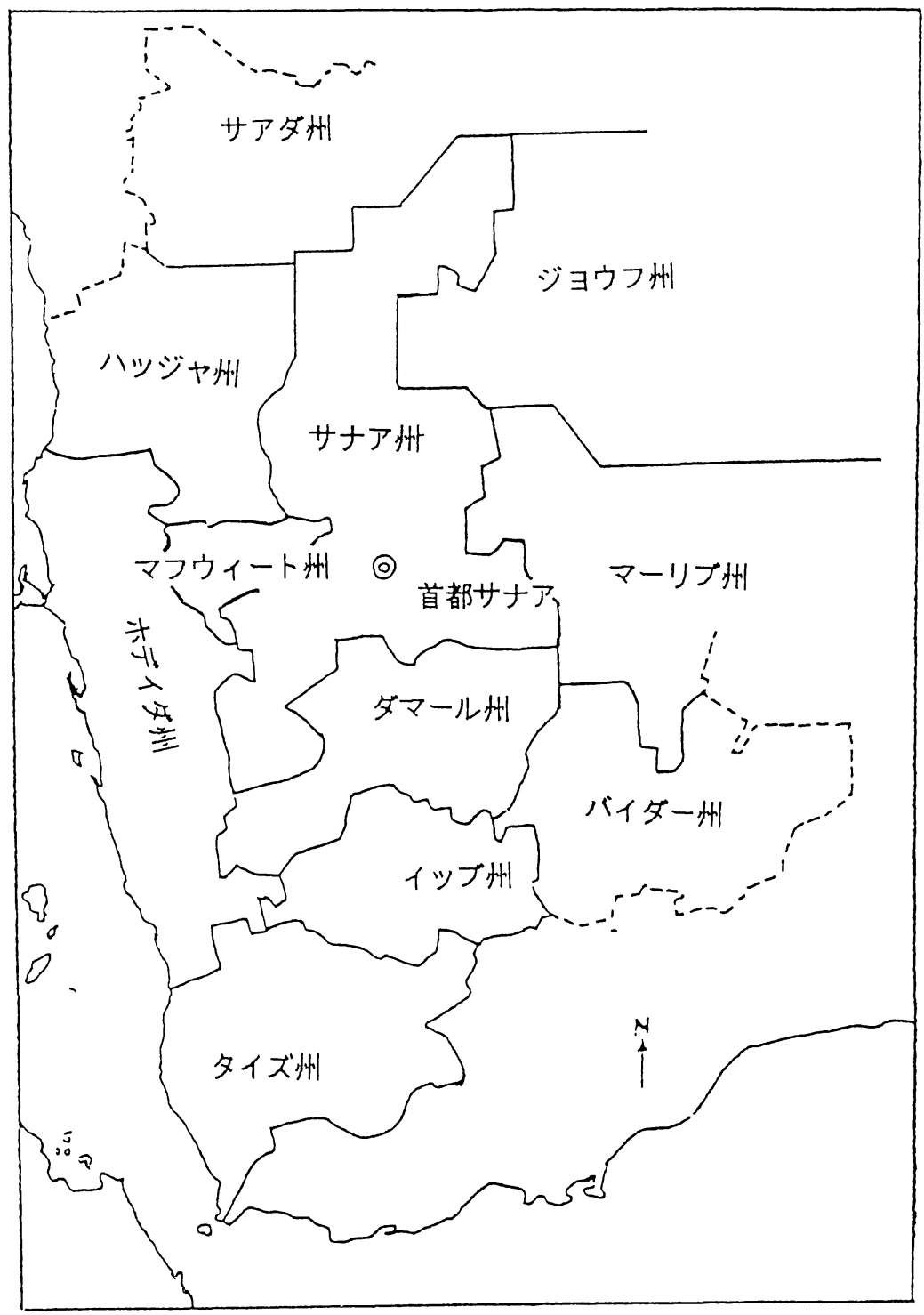

